\title{
THE CLASSICAL AMERICAN DOCTRINE OF "THE SEPARATION OF POWERS"*
}

\author{
MaICOLM P. Sharp†
}

I

T THE familiar idea that it is not the elimination of classes, but the balance of different classes' power, that is the essential feature of democracy, is given vividness by the present course of events. Workers and owners are seeking a better balance of power in the control of industrial organization. The many and the few play their parts in the direction of financial policy. The legislature and executive, particularly at Washington, are seen in a new relationship. We are told that the idea is an illusion, bound to disappear in self-contradiction and strife, by spokesmen for "communists" and "fascists" in Europe.

The theory of the balance of power, the "mixed government," has of course affected in many ways the development of economic institutions and the structure of government in the United States. The fear of power concentrated in the hands of any single class or group has, among other things, influenced the doctrine of the separation of powers among the various organs of government. It is not that there is always a clear-cut distinction between the functions of legislation and administration, between the legislative, executive, and judicial "powers." Nor is it supposed that the functions of government can or should be distributed in any perfectly systematic way to different organs. Impeachment is a familiar power of legislative bodies; the veto and the pardon belong to the executive.

\footnotetext{
* Most of the substance of this paper was prepared and read in a seminar conducted by Professor Josef Redlich, at the Harvard Law School, in r926-r927. It developes a theme referred to in Movement in Supreme Court Adjudication, 46 Harv. L. Rev. 36I, 364-365 (I933). A full and somewhat different treatment of the subject is Erlick, La Séparation des pouvoirs et la convention fédérale de I787 (I926). See also Corwin, The Progress of Constitutional Theory between the Declaration of Independence and the Meeting of the Philadelphia Convention, $30 \mathrm{Am}$. Hist. Rev. 5II (1925); Carpenter, The Separation of Powers in the Eighteenth Century, 22 Am. Pol. Sci. Rev. 32 (I928); Rockow, Bentham on the Theory of Second Chambers, $22 \mathrm{Am}$. Pol. Sci. Rev. 576 (1928); Wright, The Origins of the Separation of Powers

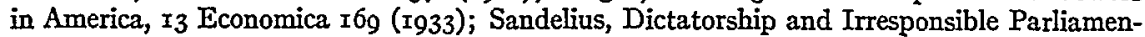
tarism-A.Study in the Government of Sweden, 49 Pol. Sci. Qu. 347 (x934); and see Friedrich, Separation of Powers, 13 Encyclopedia of the Social Sciences 663 (r934).

The special and distinct, though related doctrine governing delegation of power is not here discussed, except in so far as some of its features may be implied in the general theory of the separation of powers. For a useful contribution to the history of principles affecting the delegation of power, see Duff and Whiteside, Delegata Potestas non Potest Delegari: A Maxim of American Constitutional Law, I4 Corn. L. Q. 168 (r929).
}

† Visiting Associate Professor of Law, University of Chicago Law School. 
The interaction of the various departments is indeed relied on in part, to keep them independent.

Rather, liberty is to be preserved and class domination checked by an organization which may delay the accomplishment by any group of its will, even at the expense of efficiency. Against the unprecedented power of relatively popular legislatures the Fathers set strong executives, both in the states and the nation.

As traditions connected with the mixed government and the separation of powers are relied on at home and challenged abroad, it may be worth while to recall some features of classic formulations of the doctrine of the separation of powers.

\section{II}

Canceling mortgages, but refusing to divide the land; increasing the power of the poor, but leaving it well-balanced by aristocratic councils and magistrates, Solon began the history of democratic compromise in the West. ${ }^{x}$ Herodotus wrote impartially of the advantages of government by the many, the few and the one, during the height of Athenian democracy.2 When the ambition of the democracy had endangered the power of Athens, Thucydides praised the conservative revolutionary government associated with the name of Theramenes:

"It was during the first period of this constitution that the Athenians appear to have enjoyed the best government that they ever did, at least in my time. For the fusion of the high and the low was effected with judgment, and this was what first enabled the state to raise up her head after her manifold disasters." 3

Similarly, Aristotle, in his Politics, seems to view with particular favor this type of "mixed government." Following earlier suggestions, ${ }^{4}$ Polybius, Greek historian of the Roman Republic, described the government of the Republic at its best as a perfect combination of democratic, aristocratic, and royal elements. ${ }^{5}$ Cicero $^{6}$ and Machiavelli ${ }^{7}$ praised governments in which all these elements are well combined.

${ }^{x}$ See 4 Cambridge Ancient History (I926), 3I-58. The increasing democratization and weakening of the chief magistrates, the archons, and the compensating rise of the generals, are an interesting feature, and a significant clue in subsequent Athenian constitutional history. For an account of the democracy in the time of Pericles, see 5 Cambridge Ancient History (1927), 98-II2. Aristotle, On the Athenian Constitution, $\$ \$ 5-12$, in describing the work of Solon, indicates also its later influence.

a Herodotus, History III, 80-82. The History is perhaps as a whole favorable to democracy. See e. g. V, 78 .

3 Thucydides, History of the Peloponnesian War (Richard Crawley's trans., I9ro), VIII, 97.

4 See, for example, A. Delatte, Essai sur la politique Pythagoricienne (I922), 40-4I, II2, 60-65, 7I-74, I2I-I24, and especially Io9-II4; Dicaearchus, (ed. Fuhr. I84I), 26 ff., I 16 , especially 27, n. IIo, $36-39$, ns. $3^{x-38}$.

5 Polybius, Histories, VI, II-I8.

${ }^{6}$ Cicero, The Republic, II, 23.

7 Discorsi, I, 2. See I Dunning, History of Political Theories (I902), 306-309. 
On the other hand, though he returned more nearly to Athenian traditions in the Laws, Plato-discouraged perhaps by the decline of Athenian government in his time-insisted on the need for wise aristocrats or kings, in the Republic and the Statesman. Expressing other influences, Tacitus thought the mixed government impractical. ${ }^{8}$ In the interests of order, and not without some qualification, St. Thomas Aquinas supported monarchy. 9 Bodin and Hobbes are well-known advocates of royal power.

The mixed government was thus in its early history a relatively democratic conception. It is closely related in classic American political writing to the separation of powers. That doctrine has, however, a separate history and meaning of its own.

Aristotle's Politics contains what is commonly taken to be the original statement of the doctrine. The Politics, ${ }^{\text {I0 }}$ without distinguishing function and organ, describes governments as divided into three parts ( $\mu$ 'o $\rho\llcorner a)$.

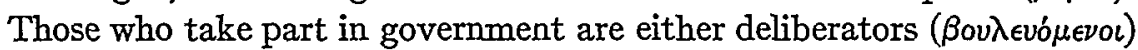

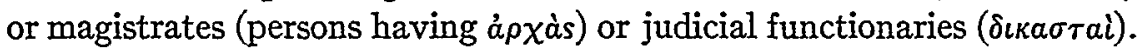
The division corresponds very well with the division of our governments into legislative, executive, and judicial departments. That the lines were not sharply drawn, however, is indicated by the observation that in some states certain magistrates ( $\pi \rho \circ \beta o u \lambda o l)$ had the deliberative function of preparing the measures on which the deliberators might pass. The account of the division of parts is purely descriptive; no reason is given for it; it is apparently not even thought of as a condition which "ought" to obtain.

Another line of thought gave a modern impetus to the development of the doctrine. John Locke was the first great English empiricist philosopher. He was enlightened by observation of, and participation in, the struggles of the Commons with the Stuart Kings. It seems likely that he gave to Americans, not only his authoritative statement of the theory of natural rights, but, through the medium of Montesquieu, the characteristic features of our doctrine of the separation of powers.

Locke, in chapter twelve of his second Essay on Civil Government, published in I690, first gave a dogmatic, normative version of the doc-

${ }^{8}$ Annals of Tacitus (Ramsey's trans., I934), IV, 33. See Boissier, Tacitus (Hutchinson's trans. I906), $135^{-144}$.

- De Regimine Principium. Of Summa Theologica, Part II, First Part, questions 95 art. 4, 97 art. 3, 105 art. I. See Schelling, Die Staats-und Soziallehre des Heiligen Thomas von Aquin (I930), II9-I29; for interesting clues to later developments in European thought, see Reynolds, Proponents of Limited Monarchy in Sixteenth Century France: Francis Hotman and Jean Bodin (I930), esp. 74-76, I47-r48, I73-r74; Moreau-Reibel, Jean Bodin et le droit public compare (I933), esp. 185-198.

so Aristotle, The Politics (Rackham's trans. Loeb Classical Library I932), IV, II. As in other instances, it seems not unlikely that the chance preference of our branch of the race for the number three has influenced the development of the doctrine. See Kroeber, Anthropology (I923), 252-3. 
trine. He distinguished clearly between function and organ. Government functions may be divided into three. The first of these three functions is commonly given to one organ of government; the other two, to a second organ of government. The functions of government ought thus to be divided between two organs, for the sake of specialization and efficiency, and for the prevention of tyranny.

The three-fold classification of functions suggests naturally (as it seems almost to have done to Montesquieu) a two-fold classification, with the first function one head, and the second and third sub-heads under a second. And there is a clear two-fold classification of organs. Moreover, the list of the three "powers" has a strange sound in the ears of an American lawyer. They are the "Legislative" and "Executive" and "Federative" powers.

"The Legislative Power is that, which has a right to direct how the Force of the Commonwealth shall be imploy'd for preserving the Community and the Members of it." The executive power must "see to the Execution of the Laws that are made, and remain in Force." In the third place:

"There is another Power in every Commonwealth, which one may call natural, because it is that which answers to the Power every Man naturally had before he entered into Society. For though in a Commonwealth the Members of it are distinct Persons still in relation to one another, and as such are governed by the Laws of the Society; yet in reference to the rest of Mankind, they make one Body, which is, as every Member of it before was, still in the state of Nature with the rest of Mankind. Hence it is, that the Controversies that happen between any Man of the Society with those that are out of it, are managed by the Publick; and an injury done to a Member of their Body, engages the whole in the reparation of it. ...

"This therefore contains the Power of War and Peace, Leagues and Alliances, and all the Transactions, with all Persons and Communities without the Commonwealth, and may be called Federative, if any one pleases."

Locke has this to say about the separation of powers, or functions, among the organs of government, and the reasons for it:

". . . because those Laws which are constantly to be Executed, and whose force is always to continue, may be made in a little time; therefore there is no need, that the Legislative should be always in Being, not having always business to do. And because it may be too great a temptation to human frailty apt to grasp at Power, for the same Persons, who have the Power of making Laws, to have also in their hands the Power to execute them, whereby they may exempt themselves from Obedience to the Laws they make, and suit the Law; both in its making, and execution, to their own private advantage, contrary to the end of Society and Government: Therefore in well order'd Commonwealths, where the good of the whole is so considered, as it ought, the Legislative Power is put into the hands of divers Persons, who duly Assembled, have by themselves, or jointly with others, a Power to make Laws, which when they have done, being separated again, they are themselves subject to the Laws, they have made; which is a new and near tie upon them to take care, that they make them for the publick good. 
"But because the Laws, that are at once, and in a short time made, have a constant and lasting Force, and need a perpetual Execution, or an attendance thereunto: Therefore 'tis necessary there should be a Power always in Being, which should see to the Execution of the Laws that are made, and remain in Force. And thus the Legislative and Executive Power come often to be separated. ...

"Though, as I said, the Executive and Federative Power of every Community be really distinct in themselves, yet they are hardly to be separated, and placed at the same time, in the hands of distinct Persons. For both of them requiring the force of the Society for their Exercise, it is almost impracticable to place the Force of the Commonwealth in distinct, and not subordinate hands; or that the Executive and Federative Power should be placed in persons, that might act separately, whereby the Force of the Publick would be under different Commands, which would be apt some time or other to cause Disorder and Ruine."

Locke's influence can be clearly traced. It goes through Montesquieu to the foundation of our American constitutions.

Montesquieu's Spirit of the Laws was published in I748. It was an urbane liberal-conservative treatise on political science. The famous chapter "Of the Constitution of England" is devoted to the separation of powers.

Without particularly distinguishing function from organ, Montesquieu starts with a three-fold classification plainly derived from Locke. He shifts almost at once to a version like Aristotle's. And before the end of the chapter we find him, without marking a clear transition, praising a mixed government of the many, the few, and the one, in terms like those of Polybius. He recognized clearly that no hard and fast line between the departments of government was possible or desirable. In this connection he gave many instances of blending: the exercise by one branch of powers which a priori one might suppose to belong to another. Finally, while recognizing the advantages of specialization in government, he was eloquent in praising the separation of powers as a protection to liberty against tyranny.

"In every government there are three sorts of power: the legislative; the executive in respect to things dependent on the law of nations; and the executive, in regard to things that depend on the civil law.

"By virtue of the first, the prince or magistrate enacts temporary or perpetual laws, and amends or abrogates those that have been already enacted. By the second, he makes peace or war, sends or receives embassies, establishes the public security, and provides against invasions. By the third, he punishes crimes, or determines the disputes that arise between individuals. The latter we shall call the judiciary power, and the other simply the executive power of the state."

Aristotle's view thus suddenly, without warning, replaces Locke's quite different view; and the two seem to be regarded as reconciled. Their reconciliation is doubtless the immediate source of our American doctrine of the separation of powers. The operations of Montesquieu's mind can only be the subject of speculation. Montesquieu was probably influenced 
by Aristotle's authority. He was a lawyer. He observed the relative independence of the English; and indeed the French, courts. At any rate, here is the passage which insured the vogue of the legislative, executive, and judicial powers.

A little later in the chapter, Montesquieu in an equally striking transition reverts to Polybius.

"Of the three powers above-mentioned the judiciary is in some measure next to nothing. (Des trois puissances dont nous avons parlé, celle de juger est en quelque façon nulle.) There remain therefore only two; and as these have need of a regulating power to temper them, the part of the legislative body composed of the nobility, is extremely proper for this very purpose....

"Here then is the fundamental constitution of the government we are treating of. The legislative body being composed of two parts, one checks the other, by the mutual privilege of refusing. They are both checked by the executive power, as the executive is by the legislative.

"These three powers should naturally form a state of repose or inaction. But as there is a necessity for movement in the course of human affairs, they are forced to move, but still to move in concert."

It is somewhat startling to find the chief authority for our American doctrine saying that "the judiciary is in some measure next to nothing"; and that the "fundamental constitution" of an ideal government requires a three-fold division into House, Senate, and Executive.

It is interesting also to notice to what an extent Montesquieu recognized and approved blending. The legislature should be assembled and prorogued by the executive. The legislature should examine into the administration of its laws. The legislature should be subject to an executive veto. The commons should impeach and the peers try the executive's ministers. The legislature should have the power generally to mitigate sentences.

One reason for the form in which Montesquieu's doctrine became lodged in the American popular mind, as well as for its influence, is probably the statement of reasons for a separation of powers. He applied these reasons to a three-fold separation into legislative, executive, and judicial departments. And Montesquieu's statement of them is persuasive and contains an important element of truth.

"The political liberty of the subject is a tranquillity of mind, arising from the opinion each person has of his safety. In order to have this liberty, it is requisite the government be so constituted as one man need not be afraid of another.

"When the legislative and executive powers are united in the same person, or in the same body of magistracy, there can be then no liberty, because apprehensions may arise, lest the same monarch or senate should enact tyrannical laws, to executive them in a tyrannical manner.

"Again, there is no liberty, if the power of judging be not separated from the legis- 
lative and executive powers. Were it joined with the legislative, the life and liberty of the subject would be exposed to arbitrary controul; for the judge would be then the legislator. Were it joined to the executive power, the judge might behave with all the violence of an oppressor.

"Miserable indeed would be the case, were the same man, or the same body whether of the nobles or of the people, to exercise those three powers, that of enacting laws, that of executing the public resolutions, and that of judging the crimes or differences of individuals."

As has been observed, Montesquieu noticed the advantages of specialization, resulting from a "separation of powers."

"Neither ought the representative body to be chosen for active resolutions, for which it is not so fit; but for the enacting of laws, or to see whether the laws already enacted be duly executed, a thing they are very capable of, and which none indeed but themselves can properly perform. .... .

"It would be needless for the legislative body to continue always assembled. .... .

"The executive power ought to be in the hands of a monarch; because this branch of government, which has always need of expedition, is better administered by one than by many: whereas, whatever depends on the legislative power, is oftentimes better regulated by many than by a single person."

Montesquieu affected Blackstone's account of the English constitution. Blackstone advocated the separation of powers, in two forms: first, the separation of powers between legislative, executive, and judicial organs; and second, in a form more commonly associated with his name, between Commons, Lords, and Crown. He seems to have thought of the functions of government as two: legislative and executive; while the organs of government would submit to two three-fold classifications; and perhaps to a two-fold classification. He recognized clearly the supremacy of Parliament, as well as the practice and propriety of blending. His reasons for advocating the separation of powers in both forms were, again, of two sorts: first, specialization and efficiency; and second, the protection of liberty. ${ }^{\mathrm{xx}}$

Ix The first volume of the Commentaries, published in 1765 , contained Blackstone's contributions to the subject.

In treating of Parliament, Blackstone said:

"In all tyrannical governments the supreme magistracy, or the right both of making and of enforcing the laws, is vested in one and the same man, or one and the same body of men; and wherever these two powers are united together there can be no public liberty. The magistrate may enact tyrannical laws, and execute them in a tyrannical manner, since he is possessed, in quality of dispenser of justice, with all the power which he, as legislator, thinks proper to give himseif. But where the legislative and executive authority are in distinct hands, the former will take care not to intrust the latter with so large a power as may tend to the subversion of its own independence, and therewith of the liberty of the subject. With us, therefore, in England, this supreme power is divided into two branches; the one legislative, to wit, the Parliament, consisting of king, lords, and commons; the other executive, consisting of the king alone." (Blackstone's Commentaries on the Law of England [21st London ed. I46-147]).

Again, in treating of the King's Prerogative, Blackstone gave an account of the part played 


\section{Blackstone also praised the distribution of powers between Commons,} Lords, and Crown. He thought that this distribution, by the creation of interacting checks, was calculated to preserve popular liberty and the ancient English forms of government, as well as to give to the Deity's three qualities of "virtue, wisdom .... power" each its proper medium of action in the political machine. ${ }^{12}$

He was, however, no doctrinaire exponent of a dogmatic theory of the separation of powers. He recognized clearly enough the supremacy of

in the performance of the government's executive function by the courts; and the development of their independence.

"Another capacity in which the king is considered in domestic affairs is as the fountain 0 justice and general conservator of the peace of the kingdom. .... The original power of judicature, by the fundamental principles of society, is lodged in the society at large; but as it would be impracticable to render complete justice to every individual by the people in their collective capacity, therefore every nation has committed that power to certain select magistrates, who, with more ease and expedition, can hear and determine complaints; and in England this authority has immemorially been exercised by the king or his substitutes. He, therefore, has alone the right of erecting courts of judicature; for, though the Constitution of the kingdom hath intrusted him with the whole executive power of the laws, it is impossible, as well as improper, that he should personally carry into execution this great and extensive trust; it is, consequently, necessary that courts should be erected to assist him in executing this power, and equally necessary that, if erected, they should be erected by his authority. ....

"It is probable, and almost certain, that in very early times, before our Constitution arrived at its full perfection, our kings, in person, often heard and determined causes between party and party. But at present, by the long and uniform usage of many ages, our kings have delegated their whole judicial power to the judges of their several courts; which are the grand depositaries of the fundamental laws of the kingdom, and have gained a known and stated jurisdiction, regulated by certain and established rules, which the crown itself cannot now alter but by act of Parliament. And, in order to maintain both the dignity and independence of the judges in the superior courts, it is enacted by the statute $x_{3}$ W. III., c. 2 , that their commissions shall be made (not, as formerly, durante bene placito, but) quamdum bene se gesserint, and their salaries ascertained and established, but that it may be lawful to remove them on the address of both houses of Parliament. And now, by the noble improvements of that law in the statute of I Geo. III., c. 23, enacted at the earnest recommendation of the king himself from the throne, the judges are continued in their offices during their good behaviour, notwithstanding any demise of the crown (which was formerly held immediately to vacate their seats), and their full salaries are absolutely secured to them during the continuance of their commissions; his majesty having been pleased to declare that 'he looked upon the independence and uprightness of the judges as essential to the impartial administration of justice, as one of the best securities of the rights and liberties of his subjects, and as most conducive to the honor of the crown'....

"In this distinct and separate existence of the judicial power in a peculiar body of men, nominated indeed, but not removable at pleasure, by the crown, consists one main preservative of the public liberty; which cannot subsist long in any state, unless the administration of common justice be in some degree separated from the legislative and also from the executive power. Were it joined with the legislative, the life, liberty, and property of the subject would be in the hands of arbitrary judges, whose decisions would be then regulated only by their own opinions, and not by any fundamental principles of law; which, though legislators may depart from, yet judges are bound to observe. Were it joined with the executive, this union might soon be an overbalance for the legislative. For which reason, by the statute of I6 Car. I., c. Io, which abolished the Court of Star Chamber, effectual care is taken to remove all judicial power out of the hands of the king's privy council, who, as then was evident from recent instances, might soon be inclined to pronounce that for law which was most agreeable to the prince or his officers. Nothing, therefore, is more to be avoided, in a free constitution, than uniting the provinces of a judge and a minister of state ...." $(266-269)$.

${ }_{22}$ Blackstone, Commentaries on the Laws of England (2 Ist London ed.), 48, 50-5I, I54-I55. 
Parliament, ${ }^{13}$ and the existence of such blendings as the parliamentary power to impeach and try ministers ${ }^{14}$ the executive power of summoning, proroguing, dismissing, ${ }^{15}$ and vetoing ${ }^{16}$ Parliament, the Crown's position as "fountain of justice," ${ }^{{ }_{7}}$ and the judicial functions of the House ofLords. ${ }^{\mathrm{x}}$

It may be that the classical and familiar classification of the organs of government in terms of the three estates of feudal society would have sufficed for American purposes, had it not been for the emphasis which the lawyers Montesquieu and Blackstone put upon the idea of an independent judiciary. Montesquieu and Blackstone had of course great authority with our American Fathers. Their teaching in this respect was moreover enforced and supplemented by the course of practical experience under colonial and early state governments.

Events in a great many of our jurisdictions must have brought clearly to the attention of leaders in the period from I775 to I 790 the dangers of legislative supremacy in general, and "legislative justice" in particular. Popular rule on a large scale was a novel experiment in any case, and one can appreciate the $a$ priori apprehension of those who carried it on. And experience strengthened the apprehension. Laws favoring debtors and dealing arbitrarily with criminals produced specific constitutional prohibitions. And exercises of "judicial power" by the legislatures, with similar effects, must have helped to impress many of the fathers with the importance of erecting an independent judiciary, with its own inviolable province. Such a judiciary would have, as well as the power to disregard unconstitutional statutes, the exclusive power to determine legal controversies.

It is obvious enough that legislative injustice and legislative justice would be, as they presumably were, popular enough with many members of the population. But men of substance, who must have had great influence in framing state constitutions and certainly dominated the framing and adoption of the federal Constitution, found their conservative interest in property and commerce threatened by legislative supremacy. And they naturally advocated, and wrote into their constitutions, not only an independent, strong executive, but another similar safeguard: an independent, strong judiciary. ${ }^{19}$

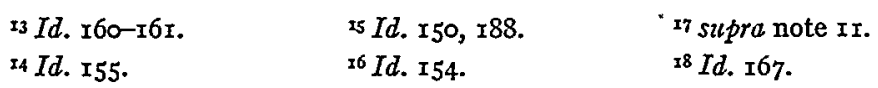

I9 See Corwin, Progress of Constitutional Theory, 30 Am. Hist. Rev. 5 II (I925); Judicial Action by the Provincial Legislature of Massachusetts, I5 Harv. L. Rev. 208 (190r). The influence of colonial experience and institutions is emphasized, and the development of our constitutions outlined, by Wright, The Origins of the Separation of Powers in America, I $_{3}$ Economica I69 (1933).

The interplay of opinion on the score of legislative supremacy and legislative justice, which 


\section{III}

The idea that a separation of three powers of government among three separate organs is a natural and desirable thing, expressed in different forms by writers who were classical authorities in America, emphasized in some respects by American experience, became a part of our informed if not "scientific" public opinion. Evidence of the state of this informed opinion on the subject is to be found in the writings of American fathers.

First, however, it is worth noting that the idea did not pass unchal-

must have gone on generally in the period of our constitution framing, is illustrated by a colloquy in the Virginia convention called to consider the federal Constitution. This colloquy took place between Governor Randolph on one side, speaking of the necessity for a strong national government, and Patrick Henry on the other, urging the adequacy of state governments.

Governor Randolph said:

"This country, so blessed, by nature, with every advantage that can render commerce profitable, through defective legislation is deprived of all the benefits and emoluments she might otherwise reap from it. We hear many complaints on the subject of located lands; a variety of competitors claiming the same lands under legislative acts, public faith protrasted, and private confidence destroyed. I ask you if our laws are reverenced. In every well-regulated community, the laws command respect. Are yours entitled to reverence? We not only see violations of the constitution, but of national principles in repeated instances. How is the fact? The history of the violations of the constitution extends from the year I 776 to this present time -violations made by formal acts of the legislature: every thing has been drawn within the legislative vortex.

"There is one example of this violation in Virginia, of a most striking and shocking naturean example so horrid, that, if I conceived my country would passively permit a repetition of it, dear as it is to me, I would seek means of expatriating myself from it. A man, who was then a citizen, was deprived of his life thus: from a mere reliance on general reports, a gentleman in the House of Delegates informed the house, that a certain man (Josiah Philips) had committed several crimes, and was running at large, perpetrating other crimes. He therefore moved for leave to attaint him; he obtained that leave instantly; no sooner did he obtain it, than he drew from his pocket a bill ready written for that effect; it was read three times in one day, and carried to the Senate. I will not say that it passed the same day through the Senate; but he was attainted very speedily and precipitately, without any proof better than vague reports. Without being confronted with his accusers and witnesses, without the privilege of calling for evidence in his behalf, he was sentenced to death, and was afterwards actually executed. Was this arbitrary deprivation of life, the dearest gift of God to man, consistent with the genius of a republican government? Is this compatible with the spirit of freedom? This, sir, has made the deepest impression on my heart, and I cannot contemplate it without horror."

The next day, Patrick Henry referred to the case:

"The honorable member has given you an elaborate account of what he judges tyrannical legislation, and an ex post facto law (in the case of Josiah Philips). He has misrepresented the facts. That man was not executed by a tyrannical stroke of power. Nor was he a Socrates. $\mathrm{He}$ was a fugitive murderer and an outlaw - a man who commanded an infamous banditti, and at a time when the war was at the most perilous stage. He committed the most cruel and shocking barbarities. He was an enemy to the human name. Those who declare war against the human race may be struck out of existence as soon as they are apprehended. He was not executed according to those beautiful legal ceremonies which are pointed out by the laws in criminal cases. The enormity of his crimes did not entitle him to it. I am truly a friend to legal forms and methods; but, sir, the occasion warranted the measure. A pirate, an outlaw, or a common enemy to all mankind, may be put to death at any time. It is justified by the laws of nature and nations.

"The honorable member tells us, then, that there are burnings and discontents in the hearts of our citizens in general, and that they are dissatisfied with their government. I have no doubt the honorable member believes this to be the case, because he says so. But I have the comfortable assurance that it is a certain fact that it is not so. The middle and the lower ranks of people have not those illuminated ideas which the well-born are so happily possessed of ...." (3 Elliott's Debates [1863], 66-67, r40.) 
lenged into our early consciousness. Following Bodin's classical French doctrine of the necessity for an undivided, unlimited secular sovereign, though with some deference to Montesquieu, Turgot uttered a criticism of the doctrine of the mixed government, which reached American ears. In a letter to Dr. Price dated March 22, I 778, printed in Dr. Price's Observations on the Importance of the American Revolution, published in I784, Turgot said:

"I am not satisfied, I own, with any constitutions which have as yet been framed by the different American States. ... I see in the greatest number an unreasonable imitation of the usages of England. Instead of bringing all the authorities into one, that of the nation, they have established different bodies, a house of representatives, a council, a governor, because England has an house of commons an house of lords and a king. They undertake to balance these different authorities as if the same equilibrium of powers which has been thought necessary to balance the enormous preponderance of royalty, could be of any use in republics, founded upon the equality of all the citizens; and as if every article which constitutes different bodies was not a source of divisions. By striving to prevent imaginary dangers, they have created real ones."

These words produced an elaborate answer, which will shortly be discussed, John Adams' Defence.

Thomas Paine in the Rights of Man, published in I792, made a less sweeping criticism of the fashionable doctrine. It is perhaps not unreasonable to suppose that Paine's ideas were current in the contemporary thought of Europe and America. Paine said:

"It has been customary to consider government under three distinct general heads. The legislative, the executive, and the judicial.

"But if we permit our judgment to act unencumbered by the habit of multiplied terms, we can perceive no more than two divisions of power, of which civil government is composed, namely, that of legislating or enacting laws, and that of executing or administering them. Everything, therefore, appertaining to civil government, classes itself under one or other of these two divisions.

"So far as regards the execution of the laws, that which is called the judicial power, is strictly and properly the executive power of every country. It is that power to which every individual has appeal, and which causes the laws to be executed; neither have we any other clear idea with respect to the official execution of the laws. In England, and also in America and France, this power begins with the magistrate, proceeds up through all the courts of judicature.

"I leave to courtiers to explain what is meant by calling monarchy the executive power. It is merely a name in which acts of government are done; and any other, or none at all, would answer the same purpose. Laws have neither more nor less authority on this account. It must be from the justness of their principles, and the interest which a nation feels therein, that they derive support; if they require any other than this, it is a sign that something in the system of government is imperfect. Laws difficult to be executed cannot be generally good." 20

20 Part II, c. IV. 
For reasons like those urged by Turgot, Benjamin Franklin was a consistent advocate of a unicameral supreme legislature. Franklin at least approved this feature of the Pernsylvania Constitution. He advocated a similar organization of the Federal Government. His position was sharply criticized by John Adams. ${ }^{2 x}$

These circumstances help to show how little clear cut and doctrinaire was our classical informed opinion on the subject. The separation of powers between a popular branch of the legislature, an aristocratic branch and an executive, seemed a principle quite as fundamental as the related and more modern principle of a separation of powers between legislative, executive, and judicial organs. The two principles were commonly discussed together, often as one, and seem to have been thought of as having much the same reasons for their application.

For the most part, in spite of criticisms, informed American opinion was in favor of the application of the principle of the separation of powers between legislative, executive, and judicial governmental bodies. Left wing and right wing united in thinking of the doctrine, in various and more or less rigid forms, as a cardinal principle of government. Writers recognized the obvious necessity for specialized adaptation to function of organ. And they were still more concerned with the utility of a division of powers, and a system of checks and balances, in protecting individuals against the dreaded tyrannies of a newly sovereign people.

Jefferson is commonly thought of as a friend of the people. He joined, however, with so sceptical a democrat as John Adams, in praising and advocating a separation of powers. Jefferson made no such systematic treatment of the subject as did Adams, Madison, and James Wilson. His views are found scattered in miscellaneous writings and letters. He believed in a three to three division of functions to legislative, executive, and judicial organs. He seemed inclined to a rather rigid view of the principle. That is, Jefferson seemed inclined to a view which would deprecate any control by one body over the activities of another, and any blending beyond the minimum which everyone agreed to be necessary. He recognized the importance of specialization. And finally, Jefferson's writings disclosed that characteristic feature of American treatment of the subject: the idea that the separation of powers would and should protect the individual and his property, not against the tyranny of kings, but against the tyranny of legislatures.

In his Notes on Virginia, published in I782, Jefferson expressly favored the principle. He thought the control by the Virginia legislature of the

${ }^{2 x}$ See Eiselen, Franklin's Political Theories (1928), 58-60, 69-7x. 
tenure and pay of executive and judicial officers an outstanding defect of the Virginia constitution. The result had been the legislature's direction of the executive and its exercise of judicial powers.

"The concentrating these (the three powers) in the same hands is precisely the definition of despotic government. It will be no alleviation that these powers will be exercised by a plurality of hands, and not by a single one. I 73 despots would surely be as oppressive as one. Let those who doubt it turn their eyes on the republic of Venice. As little will it avail us that they are chosen by ourselves. An elective despotism was not the government we fought for, but one which should not only be founded on free principles, but in which the powers of government should be so divided and balanced among several bodies of magistracy, as that no one could transcend their legal limits, without being effectually checked and restrained by the others."22

In a letter to Edward Carrington, dated Paris, August 4, I787, Jefferson urged the advantages in point of efficiency of a separation in the federal government of the three powers:

"I think it very material to separate in the hands of Congress the Executive and Legislative powers, as the Judiciary already are in some degree. This I hope will be done. The want of it has been the source of more evil than we have experienced from any other cause. Nothing is so embarrassing nor so mischievous in a great assembly as the details of execution. The smallest trifle of that kind occupies as long as the most important act of legislation, and takes place of everything else. Let any man recollect, or look over, the files of Congress, he will observe the most important propositions hanging over from week to week and month to month, till the occasions have past them, and the thing never done. I have ever viewed the executive details as the greatest cause of evil to us, because they in fact place us as if we had no federal head, by diverting the attention of that head from great to small objects; and should this division of power not be recommended by the Convention, it is my opinion Congress should make it itself by establishing an Executive committee." ${ }_{23}$

In a letter to John Adams dated Paris, September $28, x 787$, Jefferson showed signs of that hardening of doctrine which has been characteristic of many writers on the separation of powers.

"The first principle of a good government is certainly a distribution of its powers into executive, judiciary, and legislative and a subdivision of the latter into two or three branches. It is a good step gained, when it is proved that the English constitution, acknowledged to be better than all which have preceded it, is only better in proportion as it has approached nearer to this distribution of powers. From this the last step is easy, to show by a comparison of our constitutions with that of England, how much more perfect they are." 24

This letter was written to acknowledge the receipt of the first volume of A Defence of the Constitutions of Government of the United States of

${ }^{22} 3$ Jefferson's Works (Ford ed. I892), 223-4. Cf. his criticism of the Articles of Confederation, on similar grounds. $x$ id., 108 .

${ }^{23} 4$ id. 424-425. $\quad 244 i d .454$. 
America against the Attack of $M$. Turgot, by John Adams. In response to the attack of $M$. Turgot, which has been quoted in the course of this paper, John Adams wrote a three volume treatise devoted to the praise and advocacy of the principle of the separation of powers. The book was written while Adams was minister to Great Britain. The first volume was published in 1787 , and was "much circulated" in the federal convention. The other two appeared the following year.

John Adams, as early as I775, had begun advocating the separation of powers. In three early letters, ${ }^{25}$ which were published and doubtless had considerable influence, Adams set forth his views on the subject. Thus in a letter written and published in pamphlet form in 1776 , Adams wrote:

"... I think a people cannot be long free, nor ever happy, whose government is in one assembly. My reasons for this opinion are as follows:-

"т. A single assembly is liable to all the vices, follies, and frailties of an individual; subject to fits of humor, starts of passion, flights of enthusiasm, partialities, or prejudices, and consequently productive of hasty results and absurd judgments. And all these errors ought to be corrected and defects supplied by some controlling power.

"2. A single assembly is apt to be avaricious, and in time will not scruple to exempt itself from burdens, which it will lay, without compunction, on its constituents.

"3. A single assembly is apt to grow ambitious, and after a time will not hesitate to vote itself perpetual. This was one fault of the Long Parliament; but more remarkably of Holland, whose assembly first voted themselves from annual to septennial, then for life, and after a course of years, that all vacancies happening by death or otherwise, should be filled by themselves, without any application to constituents at all.

"4. A representative assembly, although extremely well qualified, and absolutely necessary, as a branch of the legislative, is unfit to exercise the executive power, for want of two essential properties, secrecy and despatch.

"5. A representative assembly is still less qualified for the judicial power, because it is too numerous, too slow, and too little skilled in the laws.

"6. Because a single assembly, possessed of all the powers of government, would make arbitrary laws for their own interest, execute all laws arbitrarily for their own interest, and adjudge all controversies in their own favor.

"But shall the whole power of legislation rest in one assembly? Most of the foregoing reasons apply equally to prove that the legislative power ought to be more complex; to which we may add, that if the legislative power is wholly in one assembly, and the executive in another, or in a single person, these two powers will oppose and encroach upon each other, until the contest shall end in war, and the whole power, legislative and executive, be usurped by the strongest.

"The judicial power, in such case, could not mediate, or hold the balance between the two contending powers, because the legislative would undermine it. And this shows the necessity, too, of giving the executive power a negative upon the legislative, otherwise this will be continually encroaching upon that.

${ }^{25} 4$ Works of John Adams (C. F. Adams ed. I85I), I85-I86, x95-I96, 205-206. On John Adams, see also Beard, The Economic Origins of Jeffersonian Democracy (r9I5), c. XI; Walsh, The Political Science of John Adams (I9I5). 
"To avoid these dangers, let a distinct assembly be constituted, as a mediator, between the two extreme branches of the legislature, that which represents the people, and that which is vested with the executive power."

The Defense, as has been said, treats the subject elaborately; and Adams' views should be studied there.

He believed alternatively that there were two or three functions of government: the legislative and executive, ${ }^{26}$ or the legislative, executive, and judicial. ${ }^{27} \mathrm{He}$ believed that the sovereign people ${ }^{28}$ should divide these powers among three bodies. These three bodies are now the popular and aristocratic branches of the legislature, and the executive; and now the legislative, executive, and judicial departments. ${ }^{29}$ In the Defence, Adams seems on the whole more concerned with the division between the two branches of the legislature and the executive. But he was concerned with both divisions.

Adams urged the importance of a strong executive..$^{30}$ For thinkers interested in the protection of the minority and its property against majority tyranny, as well as in efficient government, a sensible article of faith was a strong executive. And it naturally carried with it, though Montesquieu had said that "the judiciary is in some measure next to nothing," a belief in an independent judiciary. ${ }^{3 \mathbf{x}}$

John Adams observed what Jefferson and he himself had at first failed to notice: that the principle of the separation of powers, and its reason, required that the legislature should not elect the executive; and he therefore advocated separate popular elections (popular in the eighteenth century sense) of legislators and executives. ${ }^{32} \mathrm{He}$ also believed in preventing interference by one department with the tenure or emoluments of another. ${ }^{33}$

Blending at one point seems to be regarded as a perfectly healthy

${ }^{26}$ See for example 4 Works of John Adams, supra note 25, 290, 579 .

${ }^{27} 4$ id. 309. See note 29 , infra.

${ }^{28} 4$ id. 308, 405; 6 id. II7, II8, I45-I46.

${ }^{29} 4$ id. $284,309,382,398,429 ; 5$ id. $452-454 ; 6$ id. Ir4, II6-II8, I27. Cf. a reference to a balance between country and city. 4 id. 553 .

${ }^{30} 4$ id. 290, 358-359, 365-366, 370-37x, 40r, 414, 497, 559, 579, 584, 587; 5 id. 67, r79-180, 288-290; $6 \mathrm{id}$. II7-II8, I22. The last two passages indeed suggest the advantages of an hereditary chief executive. While at one point, Adams expressed a preference for an aristocracy as compared with any other single class government ( 5 id. $238 ; c f .4$ id. $359 ; 6$ id. 124), yet the prevention of aristocratic rule is a recurring argument in the passages cited, for a strong executive and a balanced government.

${ }^{3 x} 4$ id. 583; 5 id. 14, 73, 79, 179-180, 452-454; 6 id. 100, rog-rIr, 155, 200-201.

${ }^{32} 4$ id. 584, (cf. 587); 6 id. I7I-I73. See supra note $30 . \quad 336$ id. 57-59. 
phenomenon. Next to England, Neuchatel receives the highest praise for its application of the principle of the separation of powers in its government. And in Neuchatel, as Adams observed, there was a considerable amount of blending. ${ }^{34}$ At another point, however, it is said that the Americans have done particularly well in that they "have carefully confined their senates to the legislative power," and kept from them other powers. ${ }^{35}$

Adams, as will have been observed, thought the argument from efficiency an important argument for the separation of powers..$^{36} \mathrm{He}$ urged the importance of having society's different orders, with their different virtues and interests, separately represented. ${ }^{37} \mathrm{He}$ suggested the advantage in framing legislation of having two bodies, each to consult with and check the other..$^{38}$ But the chief argument which he advanced was the importance of the device of a separation of powers as a protection against tyranny.

The Puritan idea that human nature is essentially corrupt is developed with a curiously non-Puritan genial cynicism. After all, perhaps it is not so much that man is corrupt; as that he is weak and equipped with strong passions. At any rate it is unsafe to trust any body of men with power. The minority will be oppressed by the majority; or even the majority by themselves. ${ }^{39}$ Pure majority rule leads naturally to the rule of faction, or to the choice by the multitude of a tyrannous dictator. $4^{\circ}$ Liberty consists in subjection only to good laws. And it is a strong, if not certain, protection to liberty-and its relative property-against popular tyranny, to have a separation of powers. ${ }^{4 \mathrm{I}}$

It is the familiar argument. But it is peculiarly elaborate and blunt.

There is often an appearance of pedantry in the book. Homer and Tacitus and Cicero are extensively cited. Plato, Polybius, Dionysius of Halicarnassus, along with Machiavelli, Harrington, Algernon Sidney, Montesquieu, Swift (from whom there are indeed some beautifully apposite quotations) are relied upon. Milton, Locke (who did not write the separation of powers into his Carolina constitution), and Hume are sharply criticized for neglect of the principle. Marchamont Nedham's unsound views receive a volume to themselves. The decline of Athens and the fall of Rome were due to a lack of the separation of powers. The early Greek and German tribes knew the principle. Ancient republics, medieval and modern Italian republics, Swiss republics, prospered or suffered as they

${ }^{34} 4$ id. $376-377$.
${ }^{35} 4$ id. 380.
${ }^{36} 4$ id. $488,582$.
${ }^{37} 4$ id. 398,4 I4; 6 id. I 88.
${ }^{38} 4$ id. 5 r8.

39 See the passages quoted, infra.

$4^{\circ} 6$ id. $x_{42}$.

${ }^{4}$ See the passages quoted, infra. 
observed or neglected the principle. Poland's misfortunes were due to the lack of a separation of powers. Through all the discussion runs the black name of M. Turgot!

There is also some confusion. An extraordinary number of governments are described; and of course not from observation. Sometimes it is impossible to piece together portions of the descriptions.

There is also questionable argument..$^{22}$ At the same time, and whatever one may think of its thesis, the book has significance.

Developing considerably some suggestions of Turgot and Dr. Price, Adams wrote:

"I shall cheerfully agree with $\mathrm{M}$. Turgot that it is very possible that laws, and even equal laws, made by common consent, may deprive the minority of the citizens of their rights. A society, by a majority, may govern itself, even by equal laws, that is by laws to which all, majority and minority, are equally subject, so as to oppress the minority. It may establish a uniformity in religion; it may restrain trade; it may confine the personal liberty of all equally, and against the judgment of many, even of the best and wisest, without reasonable motives, use, or benefit. We may go farther, and say that a nation may be unanimous in consenting to a law restraining its natural liberty, property, and commerce, and its moral and religious liberties too, to a degree that may be prejudicial to the nation and to every individual in it. A nation of catholics might unanimously consent to prohibit labor upon one half the days in the year, as fast days. The whole American nation might unanimously consent to a Sunday law and a warden act, which should deprive them of the use of their limbs one day in seven. A nation may unanimously agree to a navigation act, which should shackle the commerce of all. Yet Dr. Price's definition of civil liberty is as liable to this objection as any other. These would be all equal laws made with common consent; these would all be acts of legitimate government. To take in M. Turgot's idea, then, we must add to Dr. Price's ideas of equal laws by common consent this other-for the general interest or the public good. But it is generally supposed that nations understand their own interest better

42 "Mr. Hume has collected, from Diodorus Siculus alone, a few massacres which happened in only sixty of the most polished years of Greece;- ${ }^{2}$ From Sybaris, 500 nobles banished; of Chians, 600 citizens; at Ephesus, 340 killed, I000 banished; of Cyrenians, 500 nobles killed, all the rest banished; the Corinthians killed $\mathrm{x} 20$, banished 500; Phaebidas banished 300 Boeotians. Upon the fall of the Lacedaemonians, democracies were restored in many cities, and severe vengeance taken of the nobles; the banished nobles returning, butchered at Phialae, in Corinth, in Megara, in Phliasia, where they killed 300 of the people; but these again revolting killed above 600 of the nobles, and banished the rest. In Arcadia, I400 banished, besides many killed; the banished retired to Sparta and Pallantium; the latter were delivered up to their countrymen, and all killed. Of the banished from Argos and Thebes, there were 500 in the Spartan army. The people, before the usurpation of Agathocles, had banished 600 nobles; afterwards that tyrant, in concurrence with the people, killed 4000 nobles, and banished 6000 ; and killed 4000 people at Gela; his brother banished 8000 from Syracuse. The inhabitants of Aegesta, to the number of 40,000 , were killed, man, woman, and child, for the sake of their money; all the relations of the Libyan army, fathers, brothers, children, killed; 7000 exiles killed after capitulation. These numbers, compared with the population of those cities, are prodigious; yet Agathocles was a man of character, and not to be suspected of wanton cruelty, contrary to the maxims of his age.'

"Such were the fashionable outrages of unbalanced parties. In the name of human and divine benevolence, is such a system as this to be recommended to Americans [by M. Turgot! in this age of the world?" (4 $i d .286-287)$. 
than another sic; and, therefore, they may be trusted to judge of the public good; and in all the cases above supposed, they will be as free as they desire to be; and, therefore, they may with great propriety be called free nations, and their constitutions free republics. There can be no way of compelling nations to be more free than they choose to be." 43

Both because the Defence is so unsystematic and uneven, and because it is so vigorous and so important, the temptation to quote a number of good passages is irresistible.

"The majesty of the people is a very venerable, sublime, and affecting idea; but, in human theory, every government, despotism, monarchy, aristocracy, and every mixture, is created by the people, continued by their sovereign will, and represents their majesty, their august body. ...."44

"The people are the fountain and original of the power of kings and lords, governors and senates, as well as the house of commons, or assembly of representatives. And if the people are sufficiently enlightened to see all the dangers that surround them, they will always be represented by a distinct personage to manage the whole executive power; a distinct senate, to be guardians of property against levellers for the purposes of plunder, to be a repository of the national tradition of public maxims, customs, and manners, and to be controllers, in turn, both of kings and their ministers on one side, and the representatives of the people on the other, when either discover a disposition to do wrong; and a distinct house of representatives, to be the guardians of the public purse, and to protect the people, in their turn, against both kings and nobles." 45

Liberty and property are not to be trusted to any absolute human sovereign.

"If Socrates and Plato, Cicero and Seneca, Hutchison and Butler are to be credited, reason is rightfully supreme in man, and therefore it would be most suitable to the reason of mankind to have no civil or political government at all. The moral government of God, and his vicegerent, Conscience, ought to be sufficient to restrain men to obedience, to justice, and benevolence, at all times and in all places; we must therefore descend from the dignity of our nature, when we think of civil government at all. But the nature of mankind is one thing, and the reason of mankind another; and the first has the same relation to the last as the whole to a part. The passions and appetites are parts of human nature, as well as reason and the moral sense. In the institution of government, it must be remembered that, although reason ought always to govern individuals, it certainly never did since the Fall, and never will, till the Millennium; and human nature must be taken as it is, as it has been, and will be." 46
${ }^{43} 4$ id. 402.
446 id. 145.
456 id. II8.

${ }_{46} 6$ id. II4-II5. Again:

“. . . the first inquiry should be, what kind of beings men are? You and I admire the fable of Tristram Shandy more than the fable of the Bees, and agree with Butler rather than Hobbes. It is weakness rather than wickedness, which renders men unfit to be trusted with unlimited power. The passions are all unlimited; nature has left them so; if they could be bounded, they would be extinct; and there is no doubt they are of indispensable importance in the present system. They certainly increase too, by exercise, like the body. The love of gold grows faster than the heap of acquisition; the love of praise increases by every gratification, till it stings like an adder, and bites like a serpent; till the man is miserable every moment when he does not snuff the incense. Ambition strengthens at every advance, and at last takes posses- 
Nor was Adams, probably, beneath the paradox of his distrust of the majority and his belief in popular sovereignty. One may consistently think that God is always with the minority-or, better, a minority, and yet believe in majority rule.

"In a monarchy, the laws, being made according to the interest of one man, or a few men, must needs be more private and partial than suits with the nature of justice; but in a commonwealth, the laws, being made by the whole people, must come up to the public interest, which is common right and justice; and if a man know not what is his own interest, who should know it? and that which is the interest of the most or greatest number of particular men, being summed up in the common vote, is the public interest." 47

It is to be wished, perhaps, that such passages as this were better reconciled with the distrustful passages; but the reconciliation can be imagined. And for our purposes, the most interesting phenomenon is the distrust.

"An excellent writer has said, somewhat incautiously, that 'a people will never oppress themselves, or invade their own rights.' This compliment, if applied to human nature, or to mankind, or to any nation or people in being or in memory, is more than has been merited.

" 'The people never think of usurping other men's rights.'

"What can this mean? Does it mean that the people never unanimously think of usurping over other men's rights? This would be trifling; for there would, by the supposition, be no other men's rights to usurp. But if the people never, jointly nor severally, think of usurping the rights of others, what occasion can there be for any government at all? Are there no robberies, burglaries, murders, adulteries, thefts, nor cheats? Is not every crime a usurpation over other men's rights? Is not a great part, I will not say the greatest part, of men detected every day in some disposition or other, stronger or weaker, more or less, to usurp over other men's rights? .... If we should extend

sion of the whole soul so absolutely that a man sees nothing in the world of importance to others or himself, but in his object. The subtlety of these three passions, which have been selected from all the others because they are aristocratical passions, in subduing all others, and even the understanding itself, if not the conscience too, until they become absolute and imperious masters of the whole mind, is a curious subject of speculation. The cunning with which they hide themselves from others, and from a man himself too; the patience with which they wait for opportunities; the torments they voluntarily suffer for a time, to secure a full enjoyment at length; the inventions, the discoveries, the contrivances they suggest to the understanding, sometimes in the dullest dunces in the world, if they could be described in writing, would pass for great genius.

"... Men should endeavor at a balance of affections and appetites, under the monarchy of reason and conscience, within, as well as at a balance of power without. ... They were intended by nature to live together in society, and in this way to restrain one another, and in general they are a very good kind of creatures; but they know each other's imbecility so well that they ought never to lead one another into temptation. [Here there is a note, found in the margin of John Adams' copy: "The majority are wicked."] Who would trust his life, liberty, and property to a madman or an assembly of them? It would be safer to confide in knaves. Five hundred or five thousand together, in an assembly, are not less liable to this extravagance than one. The nation that commits its affairs to a single assembly will assuredly find that its passions and desires augment as fast as those of a king. And, therefore, a constitution with a single assembly must be essentially defective." ( 4 id. 406-407.)

${ }^{47} 4$ id. 405 . 
our candor so far as to own that the majority of men are generally under the dominion of benevolence and good intentions, yet, it must be confessed that a vast majority frequently transgress; and, what is more directly to the point, not only a majority, but almost all, confine their benevolence to their families, relations, personal friends, parish, village, city, county, province, and that very few, indeed, extend it impartially to the whole community. Now, grant but this truth, and the question is decided. If a majority are capable of preferring their own private interest, or that of their families, counties, and party, to that of the nation collectively, some provision must be made in the constitution, in favor of justice, to compel all to respect the common right, the public good, the universal law, in preference to all private and partial considerations." ${ }_{48}$

Adams was at any rate far from a placid individualism, such as that to which even the great father of political economy at times yielded. It was not the "invisible hand" of God that Adams saw operating by self-interest.

"If the first part of the proposition, namely, that "the people never think of usurping over other men's rights,' cannot be admitted, is the second, namely, 'they mind which way to preserve their own,' better founded?

"There is in every nation and people under heaven a large proportion of persons who take no rational and prudent precautions to preserve what they have, much less to acquire more. Indolence is the natural character of man, to such a degree that nothing but the necessities of hunger, thirst, and other wants equally pressing, can stimulate him to action, until education is introduced in civilized societies, and the strongest motives of ambition to excel in arts, trades, and professions, are established in the minds of all men. Until this emulation is introduced, the lazy savage holds property in too little estimation to give himself trouble for the preservation or acquisition of it." 49

Adams uses a text somewhat remote from his point, to introduce his economic theories; but the basic importance of his economics, for his theory of the separation of powers, is striking.

48 "The proposition of our author, then, should be reversed, and it should have been said, that they mind so much their own, that they never think enough of others. Suppose a nation, rich and poor, high and low, ten millions in number, all assembled together; not more than one or two millions will have lands, houses, or any personal property; if we take into account the women and children, or even if we leave them out of the question, a great majority of every nation is wholly destitute of property, except a small quantity of clothes, and a few trifles of other movables. Would Mr. Nedham be responsible that, if all were to be decided by a vote of the majority, the eight or nine millions who have no property, would not think of usurping over the rights of the one or two millions who have? Property is surely a right of mankind as really as liberty. Perhaps, at first, prejudice, habit, shame or fear, principle or religion, would restrain the poor from attacking the rich, and the idle from usurping on the industrious: but the time would not be long before courage and enterprise would come, and pretexts be invented by degrees, to countenance the majority in dividing all the property among them, or at least, in sharing it equally with its present possessors. Debts would be abolished first; taxes laid heavy on the rich, and not at all on the others; and at last a downright equal division of every thing be demanded, and voted. What would be the consequence of this? The idle, the vicious, the intemperate, would rush into the utmost extravagance of debauchery, sell and spend all their share, and then demand a new division of those who purchased from them. The moment the idea is admitted into society, that property is not as sacred as the laws of God, and that there is not a force of law and public justice to protect it, anarchy and tyranny commence. If 'Thou shalt not covet,' and 'Thou shalt not steal', were not commandments of Heaven, they must be made inviolable precepts in every society, before it can be civilized or made free." (6 id. 7-9.)

496 id. 9. 
"It is very easy to flatter the democratical portion of society, by making such distinctions between them and the monarchical and aristocratical; but flattery is as base an artifice, and as pernicious a vice, when offered to the people, as when given to the others. There is no reason to believe the one much honester or wiser than the other; they are all of the same clay; their minds and bodies are alike. The two latter have more knowledge and sagacity, derived from education, and more advantages for acquiring wisdom and virtue. As to usurping others' rights, they are all three equally guilty when unlimited in power. No wise man will trust either with an opportunity; and every judicious legislator will set all three to watch and control each other. . . ."so

One must think himself back to Adams' times, with their recent experiences under the Confederation and their uncertainty about the untried experiment of large scale democracy to appreciate fully the force of his argument.

"The next inquiry is, concerning the administration of justice. Shall every criminal be brought before this assembly and tried? Shall he be there accused before five hundred men? witnesses introduced, counsel heard? This again would take more than the whole year; and no man, after all, would consider his life, liberty, or property, safe in such a tribunal. These all depend upon the disquisitions of the counsel, the knowledge of the law in the judges, the confrontation of parties and witnesses, the forms of proceedings, by which the facts and the law are fairly stated before the jury for their decision, the rules of evidence, by which the attention of the jury is confined to proper points, and the artifices of parties and counsel avoided. An assembly of five hundred men are totally incapable of this order, as well as knowledge. . . .

"Will it be said that the assembly shall appoint committees to try causes? But who

50 6 id. ro. Again:

"Though we allow benevolence and generous affection to exist in the human breast, yet every moral theorist will admit the selfish passions in the generality of men to be the strongest. There are few who love the public better than themselves, though all may have some affection for the public. We are not, indeed, commanded to love our neighbor better than ourselves. Self-interest, private avidity, ambition, and avarice, will exist in every state of society, and under every form of government. A succession of powers and persons, by frequent elections, will not lessen these passions in any case, in a governor, senator, or representative; nor will the apprehension of an approaching election restrain them from indulgence if they have the power. The only remedy is to take away the power, by controlling the selfish avidity of the governor, by the senate and house; of the senate, by the governor and house; and of the house, by the governor and senate. Of all possible forms of government, a sovereignty in one assembly, successively chosen by the people, is perhaps the best calculated to facilitate the gratification of self-love, and the pursuit of the private interest of a few individuals; a few eminent conspicuous characters will be continued in their seats in the sovereign assembly, from one election to another, whatever changes are made in the seats around them; by superior art, address, and opulence, by more splendid birth, reputations, and connections, they will be able to intrigue with the people and their leaders, out of doors, until they worm out most of their opposers, and introduce their friends; to this end, they will bestow all offices, contracts, privileges in commerce, and other emoluments, on the latter and their connections, and throw every vexation and disappointment in the way of the former, until they establish such a system of hopes and fears throughout the state, as shall enable them to carry a majority in every fresh election of the house. The judges will be appointed by them and their party, and of consequence will be obsequious enough to their inclinations. The whole judicial authority, as well as the executive, will be employed, perverted, and prostituted to the purposes of electioneering. No justice will be attainable, nor will innocence or virtue be safe, in the judicial courts, but for the friends of the prevailing leaders; legal prosecutions will be instituted and carried on against opposers, to their vexation and ruin; and as they have the public purse at command, as well as the executive and judicial power, the public money will be expended in the same way." (6id. 57-58.) 
are to make these appointments? Will not a few haughty palatines in the assembly have influence enough to determine the election in favor of their friends and will not this make the judges the tools of a party? If the leaders are divided into parties, will not one prevail at one year, and another the next and will not this introduce the most wretched of servitudes, an uncertain jurisprudence?"'s2

Much space has been devoted to John Adams. He wrote an outstanding early American book, almost a treatise on government; and his treatise was devoted expressly to advocacy of a separation of powers. He seems to furnish a fair index to the state of informed and influential opinion at his time. He must have had great influence in molding that opinion, and in determining the manner in which it expressed itself in constitutions. His theoretical and controversial writings appeared at crucial times. $\mathrm{He}$ was largely responsible for the first Massachusetts constitution. Where other men, perhaps equally clear-sighted, were more discreet, Adams, with his honest courage, has left us elaborate suggestions about the forces which produced our doctrine of the separation of powers. Finally, his arguments in favor of the separation of powers, while they may not be wholly convincing, are of the sort which one can afford to consider.

Charles Francis Adams, in an editor's preface, speaking of the Defence, said:

"The first volume was printed and published in octavo form, as a complete work, by C. Dilley, in London, in the year 1787 . It was forthwith transmitted to the United States, where it arrived in the midst of the agitation caused by the assembling of the convention to form the federal constitution. An edition in duodecimo was immediately printed in Boston, another in New York, and another in Philadelphia, by Hall and Sellers, which was much circulated in the convention, and undoubtedly contributed somewhat to give a direction to the opinions of the members. Encouraged by the favorable reception of this volume, the author redoubled his efforts, and in the succeeding year brought out two additional ones. He would have done better had he allowed himself further time. But the French Revolution was impending, the federal constitution was struggling against popular opposition, and the public attention of all Europe was more than ever drawn to the examination of republican forms." ${ }^{52}$

Madison's chief theoretical contribution to the doctrine of the separation of powers was made to aid the Constitution in its struggle against "popular opposition." The Federalist papers, in defense of the proposed federal Constitution, appeared in 1787 and I788. In the joint work of Hamilton, Madison, and Jay, Madison had the task among others, of explaining the principle of the separation of powers, and proving that the framers of the Constitution had not disregarded it. ${ }^{53}$

Madison did not argue that the principle was a good one. The virtue of the principle was the premise with which he started, accepted both by

$$
{ }_{5 x} 4 \text { id. } 583-584 . \quad \quad s_{4} 4 \text { id. } 275-6 . \quad \quad s_{3} \text { The Federalist, ns. 47-5r. }
$$


him and by the persons to whom he addressed his arguments. The speculations of Aristotle, Locke, Montesquieu, Blackstone, Jefferson, and John Adams had done their work. The experience of the colonies, the young states, and the Confederation, and the adoption of state constitutions providing for the separation of powers had helped to make the principle a familiar axiom of government. The informed and influential opinion of the time believed firmly in the principle. Madison's practical task was to persuade the leaders and the people that it had been observed.

It is curious to speculate about Madison's attitude toward the dogma. One may suspect that his scholarship enabled him to observe its confused origin. One may suspect that his critical sense led him to think that its virtues might be exaggerated. He quoted Montesquieu; and expressed some enthusiasm. Then he went on to show that there was nothing inconsistent in the Constitution. The emphasis of his discussion was on the dogma's limitations.

Madison assumed that the powers were the legislative, executive, and judicial; and that they were to be divided each to one of three independent departments of government. He recognized that one implication was that no department ought to control the appointment, tenure or emoluments of another; and that a second implication was that each department ought to have its inviolable sphere of action. At the same time, he urged that the classical statements and examples of the principle indicated that the doctrine was not to be rigidly, but flexibly, applied. There was nothing seriously irregular in giving to the Senate and the President the power to appoint officers and judges, or in joining the Senate and the President in making treaties, or giving a veto over legislation to the President. Montesquieu's model, the British Constitution, and all of the thirteen state constitutions, were carefully examined, and the many instances of departure from a rigid application of the principle of the separation of powers were accumulated.

Madison recognized clearly that a government could operate efficiently only if it were made flexible by blending. The belief was, moreover, a characteristic feature of Madison's theory that the separation of powers itself could be preserved only by blending. Taking up an idea which earlier writers had entertained, but had not fully developed, Madison argued elaborately that the only practicable way to provide for the separation of powers was to give to each department the incentive and strength to resist the encroachments of the other. Much strength came from blending. The power of Congress ought, for example, to be balanced by an executive veto. 
Madison did not use that example, but it was familiar; and it suggests another characteristic feature of his theory. Whatever Madison may have felt about the dogma of the three-fold separation of powers, he certainly agreed with others of his contemporaries in fearing legislative bodies. $\mathrm{He}$ favored a relatively weak legislature and a relatively strong executive. Like Jefferson, and unlike Adams, Madison commonly spoke, not of popular tyranny, but of official tyranny in legislation. Doubtless the three were all thinking of the same phenomenon. And with Madison protection against legislative tyranny becomes plainly the reason for the-or aseparation of powers. As the legislature in a democracy has naturally, as experience had shown, the greatest power, this power must be checked by a division of the legislature into two branches, and the creation of an independent, strong executive.

Madison's most famous statement on the subject, is perhaps his statement of his own conclusions about blending and a flexible application of the principle of the separation of powers.

"The oracle who is always consulted and cited on this subject, is the celebrated Montesquieu. If he be not the author of this invaluable precept in the science of politics, he has the merit at least of displaying and recommending it most effectually to the attention of mankind. Let us endeavour, in the first place, to ascertain his meaning on this point.

"The British constitution was to Montesquieu, what Homer has been to the didactic writers on epic poetry....

"On the slightest view of the British constitution, we must perceive that the legislative, executive, and judiciary departments are by no means totally separate and distinct from each other. The executive magistrate forms an integral part of the legislative authority. He alone has the prerogative of making treaties with foreign sovereigns, which, when made, have, under certain limitations, the force of legislative acts. All the members of the judiciary department are appointed by him; can be removed by him on the address of the two houses of parliament, and form, when he pleases to consult them, one of his constitutional councils. One branch of the legislative department forms also a great constitutional council to the executive chief; as, on another hand, it is the sole depositary of judicial power in cases of impeachment, and is invested with the supreme appellate jurisdiction in all other cases. The judges again are so far connected with the legislative department, as often to attend and participate in its deliberations, though not admitted to a legislative vote.

"From these facts, by which Montesquieu was guided, it may clearly be inferred, that in saying, 'there can be no liberty, where the legislative and executive powers are united in the same person, or body of magistrates'; or, 'if the power of judging be not separated from the legislative and executive powers,' he did not mean that these departments ought to have no partial agency in, or no control over, the acts of each other. His meaning, as his own words import, and still more conclusively as illustrated by the example in his eye, can amount to no more than this, that where the whole power of one department is exercised by the same hands which possess the whole power of another department, the fundamental principles of a free constitution are subverted." 
It will be observed that Madison's argument required him to urge that the principle means only that each department should exercise substantially all of its appropriate powers. It is striking-if not, perhaps, very significant-that Madison's statement goes so much further in rejecting a rigid version of the principle.

A cardinal article of Madison's faith was the value of a strong executive. He thought the power and organization of a representative legislature made it necessary to create a strong president. ${ }^{54}$

He adduced the experiences of Virginia and Pennsylvania, in support of his position. Adams' view of the dangers of popular tyranny were probably not very far from Madison's views of the dangers of legislative tyranny. It is interesting to see how Madison's personality, his political theories, and perhaps his sense of the practical exigencies of the moment, gave a calm and popular tone to an argument corresponding to that which Adams had stated with passionate, if sometimes amused, contempt.

Madison was particularly concerned with inquiring about the proper means of preserving a separation of powers. He observed that a paper separation, such as had been relied on by some of the states, was useless. This amounted to no more than putting faith in the faithless legislature. He discussed at length proposals for referring to the people in convention questions of limitations on the powers of government, either at the request of two departments, or at stated periods. These proposals were defective, said Madison, chiefly because they increased the danger which ought to be guarded against, by submitting questions to factious assemblies, whose

${ }^{54}$ "In a government where numerous and extensive prerogatives are placed in the hands of an hereditary monarch, the executive department is very justly regarded as the source of danger, and watched with all the jealousy which a zeal for liberty ought to inspire. In a democracy, where a multitude of people exercise in person the legislative functions, and are continually exposed, by their incapacity for regular deliberation and concerted measures, to the ambitious intrigues of their executive magistrates, tyranny may well be apprehended on some favourable emergency, to start up in the same quarter. But in a representative republic, where the executive magistracy is carefully limited, both in the extent and the duration of its power; and where the legislative power is exercised by an assembly, which is inspired by a supposed influence over the people, with an intrepid confidence in its own strength; which is sufficiently numerous to feel all the passions which actuate a multitude; yet not so numerous as to be incapable of pursuing the objects of its passions, by means which reason prescribes; it is against the enterprising ambition of this department, that the people ought to indulge all their jealousy, and exhaust all their precautions.

"The legislative department derives a superiority in our government from other circumstances. Its constitutional powers being at once more extensive, and less susceptible of precise limits, it can, with the greater facility, mask, under complicated and indirect measures, the encroachments which it makes on the coordinate departments. It is not unfrequently a question of real nicety in legislative bodies, whether the operation of a particular measure will or will not extend beyond the legislative sphere. On the other side, the executive power being restrained within a narrower compass, and being more simple in its nature; and the judiciary being described by landmarks, still less uncertain, projects of usurpation by either of these departments would immediately betray and defeat themselves. Nor is this all: as the legislative department alone has access to the pockets of the people, and has in some constitutions full discretion, and in all a prevailing influence over the pecuniary rewards of those who fill the other departments; a dependence is thus created in the latter, which gives still greater facility to the encroachments of the former." 
views would be subject particularly to legislative influence. The legislature is the numerous branch of the government, and the one most closely in touch with the people; and its members would be likely to be elected to the proposed conventions.

Madison proposed to secure the observation of the principle of the separation of powers, first, by independent selection of each branch of government, except the judiciary, and independent tenure of office; and second, by giving to each department the incentive and power to resist encroachments by another.

"But the great security against a gradual concentration of the several powers in the same department consists in giving to those who administer each department, the necessary constitutional means, and personal motives, to resist encroachments of the others. The provision for defence must in this as in all other cases, be made commensurate to the danger of attack. Ambition must be made to counteract ambition. The interest of the man, must be connected with the constitutional rights of the place. It may be a reflection on human nature, that such devices should be necessary to control the abuses of government. But what is government itself, but the greatest of all reflections on human nature? If men were angels, no government would be necessary. If angels were to govern men, neither external nor internal controls on government would be necessary. In framing a government which is to be administered by men over men, the great difficulty lies in this: you must first enable the government to control the governed; and in the next place oblige it to control itself. A dependence on the people is, no doubt, the primary control on the government; but experience has taught mankind the necessity of auxiliary precautions.

"This policy of supplying, by opposite and rival interests, the defect of better motives, might be traced through the whole system of human affairs, private as well as public. We see it particularly displayed in all the subordinate distributions of power; where the constant aim is, to divide and arrange the several offices in such a manner as that each may be a check on the other; that the private interest of every individual may be a sentinel over the public rights. These inventions of prudence cannot be less requisite in the distribution of the supreme powers of the state.

"But it is not possible to give to each department an equal power of self-defence. In republican government, the legislative authority necessarily predominates. The remedy for this inconveniency is, to divide the legislature into different branches; and to render them, by different modes of election, and different principles of action, as little connected with each other, as the nature of their common functions, and their common dependence on the society, will admit. It may even be necessary to guard against dangerous encroachments by still further precautions. As the weight of the legislative authority requires that it should be thus divided, the weakness of the executive may require, on the other hand, that it should be fortified. An absolute negative on the legislature, appears, at first view, to be the natural defence with which the executive magistrate should be armed. But perhaps it would be neither altogether safe, nor alone sufficient. On ordinary occasions, it might not be exerted with the requisite firmness; and on extraordinary occasions, it might be perfidiously abused. May not this defect of an absolute negative be supplied by some qualified connexion between 
this weaker department, and the weaker branch of the stronger department, by which the latter may be led to support the constitutional rights of the former, without being too much detached from the rights of its own department?"

It will be observed that the argument for a bi-cameral legislature is no longer drawn from the need for a representation of all classes, but from the necessity of weakening the legislature as a protection against legislative tyranny.

Framed under the influence of these ideas, and thus defended, the Constitution was adopted; and the process of exposition began.

Farrand credits Madison and James Wilson with the greatest influence, besides Washington's, in securing the adoption of the federal Constitution in its present form. ${ }^{55}$ Wilson was the author of an early and doubtless influential exposition of the Constitution. He was a member of the Supreme Court of the United States, at its origin. It is, therefore, interesting to see what were his views about the separation of powers.

The motif which we have heard announced by Jefferson, and suggested by others, is taken up and developed by Wilson. Hitherto, intelligence has struggled in some confusion, to create a rough and ready device for curbing certain human passions. Now the device is created; and the characteristics of a discovery in physics or engineering are attributed to the resulting organization.

The "rationalist" mode of judicial thought is today out of fashion. But was there not a certain wisdom in it, even on our own familiar assumptions? The judges, sometimes perhaps without consciously considering the economics of problems, often certainly without express discussion of economics, announced solutions as pure rules of law. What their manner of judgment lacked in persuasiveness for our day, it may well have made up, in respectability and authority, for their own day. And it was not inconsistent with a shrewd understanding of practical issues. Chief Justice Marshall, in deciding that a bank might be created by Congress, made very little analysis of the financial needs and interests of government. $\mathrm{He}$ undoubtedly understood them; but, following the traditions of the day, he preferred to give his judgment a certain universal and poetical finality. One with a taste for classical forms must have found a certain aesthetic relief in passing from the struggling ideas of the other fathers to James Wilson's beautiful account of the separation of powers.

In the federal and Pennsylvania conventions, and later in his lectures on the Constitution, Wilson expounded a rather rigid, doctrinaire, symmetrical version of the principle of the separation of powers. Three dif-

ss Farrand, The Framing of the Constitution of the United States (I9r3), I96-rg9. 
ferent powers were, as they should have been, by the Constitution apportioned to three different departments. These departments were a divided legislature, a single, strong executive, and an independent judiciary. Neither department could control another. Blending was minimized; or where, as in the case of the Senate, it had to be admitted, it was criticized. Madison's theory that the means of preserving a balance should be the resistance of each department to the encroachments of each other, was taken up and developed. In this connection, the idea of judicial review, familiar to the fathers, was endorsed. The practical reasons for the application of the principle were said to be efficiency, consultation, and the prevention of tyranny, particularly legislative tyranny.

Wilson expounded his version of the separation of powers in one of a series of lectures which he gave as professor of law in the College of Philadelphia in the winter of $\mathrm{r} 790-\mathrm{r} 79 \mathrm{r}$.

"The powers of government are usually, and with propriety, arranged under three great divisions; the legislative authority, the executive authority, and the judicial authority. Let us consider each, as its greatness deserves to be considered.

"The first remark, which I shall make on the structure of the legislative power, is, that it ought to be divided. In support of this position, which is, indeed, one of the most important in both the theory and the practice of government, many arguments may be advanced. Let me introduce one, by the declaration of an admired judge, whose manly candor must charm every generous mind. 'It is the glory and happiness of our excellent constitution, that, to prevent any injustice, no man is concluded by the first judgment; but that, if he apprehends himself to be aggrieved, he has another court, to which he may resort for relief. For my part, I can say, that it is a consideration of great comfort to me, that, if I do err, my judgment is not conclusive to the party; but my mistake may be rectified, and so no injustice be done.' Is less skill requiredshould less caution be observed-in making laws, than in explaining them? Are mistakes less likely to happen - are they less dangerous-is it less necessary to prevent or rectify them, in the former case, than in the latter? Which is most necessary: to preserve the streams, or to preserve the fountain from becoming turbid?

"But the danger arising from mistakes and inaccuracies is not the only or greatest one, to be apprehended from a single body possessed of legislative power. ...

"A single legislature is calculated to unite in it all the pernicious qualities of the different extremes of bad government. It produces general weakness, inactivity, and confusion; and these are intermixed with sudden and violent fits of despotism, injustice, and cruelty.

"But I will take the subject a little deeper; it is of the utmost consequence that it be fully discussed. In private life, how often and how fatally are we seduced, by our passions and by our prejudices, from those paths, which would lead us to our true interests? But are passions and prejudices less frequently to be found in public bodies, than in individuals? Are they less powerful? Do they not become inflamed by mutual imitation and example? Will they not, if unrestrained, produce the most mischievous effects? Ye, who are versed in the science of human nature-ye, who have viewed it in 
the faithful mirror of history-tell us, for you know, what answer should be given to these questions. Cannot you point out instances, in which the people have become the miserable victims of passions, operating upon their government without restraint? Cannot you point out other instances, in which the violence of one part of the government has been happily controlled by the constitutional interposition of another part?"

Wilson expresses his fear of legislative tyranny in urging that two branches of the legislature should be a protection, each against the other. Doubtless, as in the case of the other Fathers, the fear affected all his views on the separation of powers..$^{56}$

Wilson used the argument from efficiency, as others had been inclined to do before him, particularly with reference to the executive.

"In planning, forming, and arranging laws, deliberation is always becoming, and always useful. But in the active scenes of government, there are emergencies, in which the man, as, in other cases, the woman, who deliberates, is lost. Secrecy may be equally necessary as despatch. But, can either secrecy or despatch be expected, when, to every enterprise, and to every step in the progress of every enterprise, mutual communication, mutual consultation, and mutual agreement among men, perhaps of discordant views, of discordant tempers and of discordant interests, are indispensably necessary? How much time will be consumed! and when it is consumed; how little business will be done! When the time is elapsed; when the business is unfinished; when the state is in distress, perhaps, on the verge of destruction; on whom shall we fix the blame? whom shall we select as the object of punishment?

"Ruinous dissensions are not the only inconveniences resulting from a numerous executive body: it is equally liable to pernicious and intriguing combinations. When the first take place, the public business is not done at all: when the last take place, it is done for mean or malicious purposes.

"If, on the other hand, the executive power of government is placed in the hands of one person, who is to direct all the subordinate officers of that department; is there not reason to expect, in his plans and conduct, promptitude, activity, firmness, consistency, and energy?"

56 "Indeed, if I mistake not, an inferior proportion of attention, in this and in most of our sister states, has been employed about these important parts of the political system [the executive and judiciary]. Laws have abounded; their multiplicity has been often a grievance; but their weak and irregular execution, and the unwise and unstable administration of justice, have been subjects of general and well grounded complaint.

"Habits contracted before the late revolution of the United States, operate, in the same manner, since that time, though very material alterations may have taken place in the objects of their operations. ...

"... it is high time that we should chastise our prejudices; and that we should look upon the different parts of government with a just and impartial eye. The executive and judicial powers are now drawn from the same source, are now animated by the same principles, and are now directed to the same ends, with the legislative authority; they who execute, and they who administer the laws, are as much the servants, and therefore as much the friends of the people, as they who make them. The character, and interest, and glory of the two former are as intimately and as necessarily connected with the happiness and prosperity of the people, as the character, and interest, and glory of the latter are. Besides; the execution of the law, and the administration of justice under the law, bring it home to the fortunes, and farms, and houses, and business of the people. Ought the executive or the judicial magistrates, then, to be considered as foreigners? Ought they to be treated with a chilling indifference?" 
Wilson urged that, contrary to the views of Paine, the judicial function was one sui generis.

"The third great division of the powers of government is the judicial authority. It is sometimes considered as a branch of the executive power; but inaccurately. When the decisions of courts of justice are made, they must, it is true, be executed; but the power of executing them is ministerial, not judicial. The judicial authority consists in applying, according to the principles of right and justice, the constitution and laws to facts and transactions in cases, in which the manner or principles of this application are disputed by the parties interested in them." "57

Wilson was, as has been said, opposed to blending. While some statements of his views might be reconciled with Madison's flexible views, an examination of his speeches in the federal and Pennsylvania conventions indicates that one is right in being impressed less by the narrow form of his statements, than by his general tendency to favor mathematical and aesthetic precision..$^{8}$

Finally, we have Wilson's theory of the interaction of the departments, including his casual assumption of the principle of judicial review. And this theory leads him to a quiet ecstasy at the simple and elaborate perfection of the tripartite system, as at the music of the spheres. ${ }^{59}$

57 Again:

"As all controversies in the community respecting life, liberty, reputation, and property, must be influenced by their judgments; and as their judgments ought to be calculated not only to do justice, but also to give general satisfaction, to inspire general confidence, and to take even from disappointed suitors - for in every cause disappointment must fall on one side- the slightest pretense of complaint; they ought to be placed in such a situation, as not only to be, but likewise to appear superior to every extrinsic circumstance, which can be supposed to have the smallest operation upon their understandings or their inclinations. In their salaries, and in their offices, they ought to be completely independent: in other words they should be removed from the most distant apprehension of being affected, in their judicial character and capacity, by anything, except their own behavior and its consequences."

${ }_{58} 8$ "Though the foregoing great powers-legislative, executive, and judicial-are all necessary to a good government; yet it is of the last importance, that each of them be preserved distinct, and unmingled, in the exercise of its separate powers, with either or with both of the others. Here every degree of confusion in the plan will produce a corresponding degree of interference, opposition, combination, or perplexity in its execution.

"Let us suppose the legislative and executive powers united in the same person: can liberty or security be expected? No...."

"Let us suppose the legislative and judicial powers united: what would be the consequence? The lives, liberties, and properties of the citizens would be committed to arbitrary judges, whose decisions would, in effect, be dictated by their own private opinions, and would not be governed by any fixed or known principles of law. For though, as judges, they might be bound to observe those principles; yet, Proteus-like, they might immediately assume the form of legislators; and, in that shape, they might escape from every fetter and obligation of law."

"Let us suppose a union of the executive and judicial powers: this union might soon be an overbalance for the legislative authority; or, if that expression is too strong, it might certainly prevent or destroy the proper and legitimate influences of that authority...."

"Let us suppose, in the last place, all the three powers of government to be united in the same man or body of men: miserable indeed would this case be! This extent of misery, however, at least in Europe, is seldom experienced; because the power of judging is generally exercised by a separate department. ..."

59 "But further; each of the great powers of government should be independent as well as 
We have examined the opinions of representative fathers about the separation of powers, expressed in their theoretical and controversial writings. These opinions furnish us an index to the state of informed and influential public opinion, at the time of the origin of our government. They themselves helped to mould opinion. They suggest the causes which produced the vogue of the principle of the separation of powers. They introduce us to the reasons for (and against) its application. We have now to see how the opinion of the time expressed itself in institutions, and particularly in the federal constitution.

distinct. When we say this; it is necessary - since the subject is of primary consequence in the science of government-that our meaning be fully understood, and accurately defined. For this position, like every other, has its limitations; and it is important to ascertain them.

"The independency of each power consists in this, that its proceedings, and the motives, views, and principles, which produce those proceedings, should be free from the remotest influence, direct or indirect, of either of the other two powers. But further than this, the independency of each power ought not to extend. Its proceedings should be formed without restraint, but, when they are once formed, they should be subject to control.

"We are now led to discover, that between these three great powers of government, there ought to be a mutual dependency. We have described their independency: let us now describe their dependency. It consists in this, that the proceedings of each, when they come forth into action and are ready to affect the whole, are liable to be examined and controlled by one or both of the others.

"So far are these different qualities of mutual dependency and mutual independency from opposing or destroying each other, that, without one, the other could not exist. Whenever the independency of one, or more than one, is lost, the mutual dependency of the other is, that moment, lost likewise: it is changed into a constant dependency of that one part on two; or, as the case may be, of those two parts on one.

"An example may illustrate the foregoing propositions. They cannot be explained too fully. The congress is intrusted with the legislative power of the United States. In preparing bills, in debating them, in passing them, in refusing to pass them, their resolutions and proceedings should be uncontrolled and uninfluenced. Here is the independency of the legislative power. But after the proceedings of the legislature are finished, so far as they depend on it, they are sent to be examined, and are subjected to a given degree of control by the head of the executive department. Here is the dependency of the legislative power. It is subject also to another given degree of control by the judiciary department, whenever the laws, though in fact passed, are found to be contradictory to the constitution.

"The salutary consequence of the mutual dependency of the great powers of government is, that if one part should, at any time, usurp more power than the constitution gives, or make an improper use of its constitutional power, one or both of the other parts may correct the abuse, or may check the usurpation.

"The total disjunction of these powers would, in the end, produce that very union, against which it seems to provide. The legislature would soon become tyrannical, and would assume to itself the rights of the executive and judicial powers.

"The important conclusion to be drawn from the premises, which we have established, is, that, in government, the perfection of the whole depends on the balance of the parts, and the balance of the parts consists in the independent exercise of their separate powers, and, when their powers are separately exercised, then in their mutual influence and operation on one another. Each part acts and is acted upon, supports and is supported, regulates and is regulated by the rest.

"It might be supposed, that these powers, thus mutually checked and controlled, would remain in a state of inaction. But there is a necessity for movement in human affairs; and these powers are forced to move, though still to move in concert. They move, indeed, in a line of direction somewhat different from that, which each, acting by itself, would have taken; but, at the same time, in a line partaking of the natural direction of each, and formed out of the natural directions of the whole-the true line of public liberty and happiness." 


\section{IV}

Again, retracing our steps, we shall see how, under the influence of forces whose traces we have seen, the idea of the separation of powers struggled to work out its implications. The fear of royal tyranny, of popular and legislative tyranny, of senatorial tyranny, of executive tyranny, determines the forms of arguments in conventions, and of institutions. There is solicitude for executive efficiency. The notion of a tripartite division, given additional popularity by the failure of the Articles of Confederation, gains in clarity. It comes to mean, not too strong a legislature, and a sufficiently strong executive. It comes to mean independent selection of the departments of government, and independent tenure of office. The interaction of departments is relied on to preserve the system. Blending is attacked and justified.

The history proceeds in its tortuous way, through the Declaration of Independence, the state constitutions, the Articles of Confederation, the federal convention and the state conventions which framed and adopted the Constitution.

One should note two things. First, there is the constant fear that individual "rights" will be violated by governmental wrongdoing. Second, while the principle of the separation of powers was early almost universally accepted, its implications only gradually and to some extent became clear. In particular, the powers and constitution of the related senate and executive, the selection of members of government, and blending, were the subjects of dispute and evolution.

We have studied the opinions which produced the early history of practice. All that can be done here, is to suggest, by a few concrete references to debates and instruments, the course which that history took.

The Declaration of Independence, with its condemnation of royal interference with colonial legislatures and courts, was in one aspect a step in the development of the separation of powers.

"He has called together legislative bodies at places unusual, uncomfortable, and distant from the repository of their public records, for the sole purpose of fatiguing them into compliance with his measures.

"He has dissolved representative houses repeatedly, for opposing, with manly firmness, his invasions on the rights of the people.

"He has refused, for a long time after such dissolutions, to cause others to be elected; whereby the legislative powers, incapable of annihilation, have returned to the people at large, for their exercise, the state remaining, in the meantime, exposed to all the dangers of invasion from without, and convulsions within.

"He has obstructed the administration of justice, by refusing his assent to laws for establishing judiciary powers. 
"He has made judges dependent on his will alone for the tenure of their offices, and the amount and payment of their salaries."

The Declaration marks strikingly the transition from the period when liberty and property seemed endangered by nobles and kings, to the period when they seemed to be in danger from popular tyranny. That the abuses which it condemned were in fact largely parliamentary, ${ }^{60}$ does not lessen its symbolical significance.

A majority of the state constitutions, by the time when Madison wrote his Federalist paper on the subject, embodied in some form the principle of the separation of powers.

A detailed history of the steps by which the principle worked itself into these early state constitutions might do much to confirm or correct our ideas of its nature and origin. Here, however, we can only suggest the rôle which the makers of the state constitutions played.

John Adams' views, expressed in his early correspondence, apparently had considerable influence on the minds of the leaders who determined the structure of the Virginia and the New York constitutions. ${ }^{6 r}$ Jefferson credited George Mason with the production of the Virginia constitution of June 29,1776 . It may be, however, that Jefferson's draft of a proposed constitution influenced the form of the formal provision for a separation of powers in that constitution.

"The Legislative, Executive, and Judiciary Departments, shall be separate and distinct, so that neither exercise the powers properly belonging to the other; nor shall any person exercise the powers of more than one of them at the same time, except that the Justices of the County Courts shall be eligible to either House of Assembly." "62

The principle, though thus expressed, was not well observed, either in Jefferson's draft of a constitution, or in the constitution itself. In both, the bi-cameral legislature, or one branch of it, was given power to choose an executive for one year, and his council, and to choose the judges of the highest court, to hold office during good behavior. We have already seen that Jefferson criticized the operation of this constitution, in enabling the legislature to exercise overwhelming power. The Constitution is not elaborate, and contains no other provisions relevant to the subject.

The New York Constitution of $I 777$, similarly, contained no very elaborate provisions for a separation of powers. While respecting the principle, it provided for a legislative council to participate in the making of appoint-

${ }^{60}$ See Becker, The Declaration of Independence (1922), 18-23. For the influence of colonial experience, see again Wright, The Origins of the Separation of Powers in America, I3 Economica 169 (r933).

6x See Nevins, The American States during and after the Revolution (I924), I22-125, I44, I60-I6I.

62 See 2 Jefferson's Works (Ford ed. 1892), 8-9, r3. 
ments, an executive and judicial council to aid in the approval or disapproval of legislation, and for a legislative supreme judicial body. In expressing the principle simply by allotting various functions to various organs, it anticipated the form of the Constitution of the United States. It has been spoken of as the best of the state constitutions, until the Massachusetts constitution. ${ }^{6}{ }^{3}$

John Adams, as a subcommittee of the Massachusetts convention, was the principal draftsman of the first Massachusetts constitution adopted in I $780 .{ }^{64}$ Adams' statement of the principle was in the form later used in the Massachusetts constitution:

"In the government of this commonwealth, the legislative department shall never exercise the executive and judicial powers, or either of them; the executive shall never exercise the legislative and judicial powers, or either of them; the judicial shall never exercise the legislative and executive powers, or either of them, to the end it may be a government of laws and not of men."

The convention modified Adams' draft by substituting two provisions for a separation of powers, the first as part of the declaration of rights, the second as a section of the chapter "The Frame of Government."

The former provision read thus:

"The judicial department of the state ought to be separate from, and independent of, the legislative and executive powers."

The latter was in conventional form:

"In the government of the Commonwealth of Massachusetts, the legislative, executive, and judicial power shall be placed in separate departments, to the end that it might be a government of laws, and not of men."

Adams had come to see that the principle required that the legislature should not elect the executive; and accordingly his draft and the constitution provided for popular annual elections of the governor, and for the immediate determination, "by standing laws," of a "fixed and permanent" salary. The bi-cameral legislature had power to elect a governor's council. The governor, "with the advice and consent of the council," appointed judicial officers, who were to hold office during good behavior. There were an executive veto, and the familiar types of blending, together with a provision for advisory judicial opinions, at the request of either branch of the legislature in Adams' draft, at the request of the senate in the final constitution.

In the meantime, in $\mathrm{I} 778$, the Articles of Confederation were adopted. Some of the Fathers seemed to think that the Articles failed largely be-

${ }^{6}$ See Nevins, supra note $6 \mathrm{I}, \mathrm{I} 58-\mathrm{I} 64$.

${ }^{64}$ See 4 Works of John Adams, supra note 25, 2x3-267. 
cause they did not provide for an independent, efficient executive, and made such scanty provision for a federal judiciary. It is Farrand's view, however, that these weaknesses were negligible in comparison with more fundamental weaknesses of the Confederation..$^{65}$ And it does seem difficult to class them in importance with such defects as the inability of the Confederation to exert its force on individuals. At the same time the weakness of the Confederation's executive seems to have impressed contemporaries.

At any rate, the Confederation partially failed; and in $I 787$ the federal constitutional convention assembled in Philadelphia. The writers and circumstances which we have been studying here produced their most impressive effect. Locke's authority in the early period of our history is well known, though his views on the separation of powers seem not to have been used by the Fathers. Blackstone's influence, as author of a universally used law book, is equally well known. But Montesquieu's authority as a writer on politics seems to have eclipsed all others. Of the authorities relied on in the debates of the federal convention, so far as they appear in Farrand's Records of the Federal Conventions, the following men were cited once: Aristotle, Demosthenes, Cicero, Plutarch, Neckar, Blackstone, Hume, Priestley, Rutherford, Lord Somers, Lord Chesterfield and Rollins, author of an Ancient History. Locke was cited twice, both times in the same speech; Vattel was cited twice separately. Montesquieu, the only person to be cited more than twice, was separately cited seven times; though only once on the separation of powers.

Jefferson's Notes on Virginia and Adams' Defence must have been in the minds of many members of the convention. They must all have recalled instances of popular legislative "tyranny" and executive ineffciency. The states had adopted the principle of the separation of powers in their constitutions. Madison and Wilson, who were later to show their familiarity with the reasons for and the implications of the separation of powers, were leading members of the convention. Farrand, as we have observed, has said that Madison and Wilson, with Washington (who presided and did not debate, but whose influence must have been important) were the strongest personal influences in forming and recommending the Constitution.

It is not surprising, therefore, that the principle of the separation of powers was accepted without any debate whatever by the members of the convention. It had become an axiom; and the only question was of applying it.

${ }_{65}$ See Farrand, supra note 55, 49-51. 
In connection with particular measures, the leaders were indeed peculiarly frank about their reasons for a belief in a separation of powers, as part of a system of checks. Madison, ${ }^{66}$ Wilson, ${ }^{67}$ Hamilton, ${ }^{68}$ Governeur Morris, ${ }^{69}$ Randolph, ${ }^{70}$ and Mason ${ }^{7 x}$ spoke bluntly about their fear of the danger to minority interests, and particularly property, from popular rule. Bedford, of Delaware, alone, seems to have had a word to say for unlimited popular rule; and his views were hardly noticed. ${ }^{72}$ For bulwarks against popular tyranny, reliance was placed particularly on the senate and executive. The importance of efficiency was urged, particularly in connection with the executive. ${ }^{73}$

All the plans ${ }^{74}$ presented to the convention provided, in some form, for the separation of powers. The Virginia Plan followed the original Virginia constitution in providing for the election by Congress of the executive and judiciary. It also provided for the association with the executive of a number of the judiciary in a council of revision. The Pinckney Plan seems to have had similar provisions for the choice of executive and judiciary. This Plan seems curiously to have joined in one section its provision for federal executive departments with its provision for a federal judiciary. The New Jersey Plan, presented on June I5, provided for a unicameral Congress, for the election by Congress of a committee executive, and for the appointment by this executive of a judiciary. Hamilton's Plan, presented to the convention on June I8, contained provisions for the organization and selection of the departments most nearly like those which eventually were embodied in the Constitution.

The convention spent over three days organizing, and the rest of the fourth listening to Governor Randolph present the Virginia Plan, and receiving the Pinckney Plan. Then the convention, while sitting as a committee of the whole, passed its first substantive resolution on Wednesday, May 30, I787. A resolution in similar, but significantly different form, was proposed by Read, seconded by C. C. Pinckney: "Resolved, That in order to carry into execution the design of the States in forming this convention and to accomplish the objects proposed by the confederation 'a more effective government consisting of a Legislative, Judiciary, and Executive ought to be established." "Instead, a resolution proposed

\footnotetext{
${ }^{66}$ I Farrand, The Records of the Federal Convention (IgrI), Io8, $\mathrm{x}_{34} 4^{-1} 3^{6}, \mathrm{I} 47,222,422-$ 423 (430-43I), 584; 2 id. Iro.

${ }^{67} \mathrm{I}$ id. $254 ; 2$ id. 300-301.

${ }^{68}$ I id. 288-289, 424.

${ }^{69} \mathrm{I} i d .5^{\mathrm{II}-5^{\mathrm{I}} 4}\left(5^{\mathrm{I}} 7^{-5} 5^{\mathrm{x}}\right)$.

${ }^{70}$ I $i d .51(58), 218$.
${ }^{7}$ I id. 428, 433 .
72 I 2 d. roo-ror.
${ }_{73}$ I id. 65, 96, 97, III-IX4, I24.
${ }^{74} 3$ it. $593 \mathrm{ff}$. for the four "plans."


by Butler, seconded by Randolph, was adopted. "Resolved that it is the opinion of this Committee that a national government ought to be established consisting of a supreme Legislative, Judiciary, and Executive."

The formal reference in one place to the three departments gradually disappeared. A draft of a proposed constitution, in the writing of Randolph with emendations in the writing of Rutledge, was included by Farrand among papers showing the work of the Committee of Detail. First came a preamble. Then came a

"First resolution-This resolution involves three particulars

"I. The style of the United States, which may continue as it now is.

" 2 . a declaration that (an) [a] supreme legislative, executive, and judiciary shall be established; and

"3. a declaration, that these departments shall be distinct, (except) and independent of each other, except in specified cases."

The draft presented by the Committee contained simply the declaration:

"The Government shall consist of supreme legislative, executive, and judicial powers."75

Even this declaration disappeared finally in the Committee of Style; and the form of the Constitution which we have today, and which gradually took its shape under the debates of the convention, and in the hands of committees, was finally adopted. In the Constitution the principle of the separation of powers is expressed not explicitly, but implicitly.

The debates, in dealing with the separation of powers, centered on specific problems.

Thus, the New Jersey Plan provided for no Senate. Pinckney, among others, defended the Plan in this respect, on the ground that there was no three estates in America. ${ }^{76}$ Madison, ${ }^{77}$ Hamilton, ${ }^{78}$ and Mason, ${ }^{79}$ however, pretty frankly urged the necessity of checking the representatives of the poor in the House by more conservative representatives in the Senate; and orthodox views prevailed.

Again, there was debate whether a relatively large Senate or a relatively small one would be a more effective check on the House. ${ }^{80}$

Randolph was the leader of a movement for an executive of three, representing three different sections of the country. ${ }^{8 x}$ He urged the danger of

75 I $i d .30,33,34 ; 2 i d .138, x 77$, for the successive statements of the principle of. I id. 42,67.

${ }^{76}$ I id. $398-404$.

77 I id. 422-423.

${ }^{78}$ I id. 424. 66-69.

${ }^{79}$ I $i d .428,433$. Cf. Governeur Morris, I $i d$. $5 x^{1}-5 \times 4$ (5x7-5x8). And see supra notes

${ }^{80}$ I $i d .5^{1-52 .} \quad 8 x \times i d .90,92$, IxO-II4. 
tyranny from a single executive, and argued that three would be sufficiently efficient. Wilson led a successful attack on this movement. ${ }^{82} \mathrm{He}$ and his party advocated a single executive, because of his advantages in point of "vigor" and "tranquillity." Madison's compromise advocacy of an executive council seems to have been found superfluous; and the proposal, discussed at two points, finally dropped..$^{83}$

The election and tenure of the Senate caused some discussion. The Virginia Plan provided for election by the House. The principle of checks required an independent election. Popular election was suggested, and the familiar method adopted, as a refinement of popular election and a natural concomitant of "the great compromise." were urged; and Hamilton even advocated life tenure, "during good behavior." It was said the longer the tenure, the more effective the check. ${ }^{85}$

The mode of election of the President occasioned great debate from time to time until almost the close of the convention. ${ }^{86}$ The Virginia Plan provided for Congressional election of the President. A strong party, led perhaps by Sherman, advocated Congressional election, and a consequent measure of executive responsibility to Congress. The advocates of this scheme seem to have been afraid of monarchy, and to have desired concessions to small state interests. Congressional election was several times accepted by the Convention, and each time accompanied by a prohibition against reëlection. Madison and Wilson and their associates finally succeeded in beating the provision. Popular election, election by governors, and finally electoral election were their substitutes. With the adoption of electoral election, a prohibition against reëlection seems to have been thought unnecessary.

Tenures of four and seven years were considered. ${ }^{87}$ Again, as in the case of the Senate, Hamilton urged tenure during good behavior. He, and it may be a considerable number with him, seem to have looked a little longingly at the idea of monarchy. ${ }^{88}$

As the Senate acquired additional powers, fear of its influence and suspicion of the evil effects of blending increased. At one time Madison considered it perhaps advisable to give to the Senate the exclusive power of concluding peace treaties. He feared that his favored executive might

${ }^{82}$ I $i d .63-75,96,254-255$.

${ }^{8}$ I $i d .70,97 ; 2$ id. 54I-542. Cf. 2 id. 638-639.

84 工 id. 59, 4IO-4I5.

85 I id. 2I8-219, 222, 299-30r, 4r5-4I6.

${ }^{86}$ I $i d .65,68,69,73,77,9$ г, т75.ff.; 2 id. 29 ff., 52 ff., 99.ff., 1то ff., 145, 402-404 (407), $497,501-502,5$ II, 5 I3.

${ }^{87} 2$ id. 525.

${ }^{88}$ I id. 299-30I. 
wish, for the sake of his own power, unduly to prolong wars. ${ }^{89}$ Madison and Wilson-the latter doubtfully-advocated the Senate's and executive's joint power to choose judges. ${ }^{90}$ But when, after the great compromise, to which he was much opposed, Wilson found a committee giving the Senate power to join in the appointment of all officers, he was much disturbed.9x ${ }^{92}$ adison ended by favoring impeachment trials of the executive, not by the Senate but by the Supreme Court. ${ }^{22}$ And the proposal to join the Senate with the President in the pardon of treason met such violent opposition that it was promptly dropped. .93

The President's powers seem to have occasioned less alarm. We have already noticed discussion of his share in treaty-making; 94 and implied that his power to pardon treason was questioned. ${ }^{95}$ Mason, as he was later to do in the Virginia convention, objected most strongly to the President's powers. He was afraid even of his power of appointment. ${ }^{96}$ Wilson advocated an absolute presidential veto; Madison, a veto to be out-voted by three-fourths of Congress; and our present provision for a veto out-voted by two-thirds of Congress was the result of pressure by those who were less anxious than those two for a strong executive. ${ }^{97}$

Farrand's Records indicates that Madison, anticipating a later specialty, had more to say than others about problems of separation of powers. Madison's speeches support perfectly the position he was later to take in the Federalist, and indicate that his fear of the legislature and his desire for a strong executive were fundamental. They also manifest that practical, flexible attitude toward the principle, which characterized Madison's later arguments on the subject.

Thus Madison, like Wilson, favored a single executive and opposed legislative election of the executive. ${ }^{98} \mathrm{He}$ opposed a provision that the executive should hold office "during good behavior." In an extended speech on this subject, Madison also referred to the importance of making the judiciary independent of other departments for their tenure of office.

${ }^{89} 2$ id. 392, 394 (395), 540, 548.

${ }^{90} \mathrm{I}$ id. Ir9-120, 232; 2 id. 4I, 42, 44, 80-83. Cf. 2 id. 389.

${ }_{9 x} 2$ id. $53^{8}-540$. Cf. 2 id. $5^{13}$, as to the danger of the Senate's influence in the election of a President.

922 id. 55 I.

932 id. 626-627. Cf. 2 id. 638, for Mason's summary of objections to the powers of the Senate.

94 See supra note 89.

95 See supra note 93. And see 2 id. 627,639.

${ }_{96}^{6}$ I id. ror, 107-ro8; 2 id. 638-639.

97 I $i d .98-100$, IO7; 2 id. 299-300, 585, 586-587. $\quad 9^{88}$ I id. 63-75, тO9-II , II4. 
He observed that the executive and judiciary were alike, and yet unlike, in that the "collective interest and security" were more in the executive's charge, and the executive had greater discretion than the judiciary. $\mathrm{He}$ cited Montesquieu, and argued strongly from the danger of legislative tyranny, for the necessity for executive independence. ${ }^{99}$

Similarly, Madison opposed a motion to make the executive removable by Congress at the request of a majority of state legislatures. Dickinson supported the motion. Conceding that the proposal violated the dogma of separation of powers, which ought to be observed as far as possible, Dickinson urged that the scheme proposed would furnish a necessary and proper check on the executive, and a guaranty of states' rights. Sherman thought that Congress should have power to remove the President "at pleasure." Mason urged the dogma against the proposal. Madison and Wilson opposed the proposal, on the ground that the device would foment faction, and that it improperly "mixed" the states with the federal government. They seem to have avoided the argument from the principle of the separation of powers, perhaps because they thought impeachment not only a better device than that proposed, but a necessary one. ${ }^{100}$

Madison, indeed, urged the necessity of impeachment of the executive, preferably with trials by the Supreme Court. King opposed it, arguing from the dogma. But Madison thought some such check necessary, even for that particular object of his concern, the executive. ${ }^{\text {xox }}$

It will be observed that Madison's views on these questions of the constitution, election, tenure and removal of the executive, prevailed. Some other serious efforts on his part to strengthen the executive-efforts in which Wilson joined him-failed.

Madison and Wilson were anxious that the convention should adopt some provision, like that in the Virginia Plan, for the association of the President and judiciary in a council of "revision" of the laws, with at least a qualified veto. ${ }^{\mathrm{I02}}$ On three occasions these two influential men joined in strenuously urging the adoption of this device. Gerry, King, and Charles Pinckney opposed the motion, on the ground that unity in the executive would alone produce responsibility. Dickinson urged the same argument against the proposal, and, in addition, relied on the dogma of a separation of powers. Williamson thought a two-thirds vote should be necessary to the passage of a law, and there should be no revision.

Madison, on the other hand, urged that the argument from the prin-

992 id. $34-35$.

${ }^{x 00}$ I id. 85-87. Tox $x i d .92 ; 2$ id. 64-69, 55x.

${ }^{102}$ I $i d$. I31, I38-140, 144; 2 id. 73-80, 298. Cf. I id. 9 I. 
ciple of a separation of powers applied equally to an executive veto, and so reduced itself to an absurdity. Great Britain had an executive veto; and it was agreed there should be such a device in the United States. In few cases would the judges have to determine cases arising under laws they had helped to frame; and in few of these would the laws be ambiguous. A council of revision would both strengthen and control the executive in the exercise of his veto. The device, so far from violating the principle of the separation of powers, in giving to the executive and judiciary a means of resisting legislative encroachments on the executive or the judiciary or on private rights, was "an auxiliary precaution in favor of the maxim."

Wilson, in supporting the same device, characteristically thought the argument from the necessity of centering responsibility applied only to strictly executive functions. This revisionary function was an "extraneous one, calculated for collateral purposes." Mercer supported the proposal as a protection against "legislative usurpation and oppression"; and Mason as a safeguard against legislative encroachment on the executive. The proposal was voted down each time.

Madison, like Wilson and others, approved the principle of judicial review. ${ }^{\mathrm{ro3}}$ Mercer of Maryland alone opposed the principle; and he only, in the course of his interesting arguments for a council of revision, by an incidental observation. ${ }^{\text {x04 }}$ Dickinson of Delaware did not like the idea; but he could suggest no substitute. ${ }^{105}$ The debate on a council of revision overshadows the incidental references to the accepted doctrine of judicial review.

Madison approved our familiar provisions with respect to the organization, choice, and tenure of the judiciary. He thought, however, that there ought to be a prohibition against increasing, as well as decreasing, specific judicial salaries, to prevent legislative interference with the courts. ${ }^{\text {ro6 }}$

By means of such discussion of details and the work of committees, after famous crises and compromises, the business of the convention was finished. When the work was completed, there were critics among the members of the convention; and some of them were concerned about the separation of powers.

Wilson had opposed giving the Senate any share in making appointments, other than judicial appointments. ${ }^{107} \mathrm{He}$ seems, on the other hand,

${ }^{103} 2 \mathrm{id} .73,74,76,78$. 1042 id. 298. $\operatorname{sos} 2$ id. 299.

${ }^{106}$ I id. II9-120, I24; 2 id. 44, 45, 429, 430.

${ }^{207} 2$ id. 538-540. Cf. I id. I19-т20; 2 id. 4I, 389. 
to have spoken in general terms in favor of some power of impeachment. ${ }^{\text {ro8 }}$ Now he sharply criticized all the blending of powers in the Senate. According to McHenry's notes, which are substantially verified by Madison's, he said, among other things:

"The Senate may exercise, the powers of legislation, and Executive and judicial powers. To make treaties legislative, to appoint officers Executive for the Executive has only the nomination, to try impeachments judicial. If this is not Aristocracy I know not what it is."

Later, in defending the Constitution, Wilson frankly expressed his dislike for the blending of powers in the Senate.

Mason followed Wilson's lead in criticizing the Senate's share in the appointment of officers. "He had he said always considered the Senate as too unwieldy and expensive for appointing officers, especially the smallest, such as tide waiters, etc." He was also suspicious of the President's powers. ${ }^{\text {ro }}$

Randolph, Mason, Gerry, and Williamson (who objected to the existence of a Vice President) objected to making the Vice President, president of the Senate, on the ground that this was to mix legislative and executive powers. ${ }^{\text {III }}$

Notwithstanding these criticisms, the new Constitution embodied the principle of the separation of powers. "All legislative Powers herein granted" went to a House and a Senate. "The executive Power" went to a President and Vice President. "The judicial Power" went to a federal judiciary.

Representatives, Senators, and the two constitutionally created executive officers were elected by different mechanisms, and for different terms. The House indeed elected the President in event of the failure of a majority of electors to agree, and the Senate, the Vice President in case of a tie. The President, "by and with the Advice and Consent of the Senate" appointed judges, who served "during good Behaviour." As Madison said, with respect to the choice of judges,

"In the constitution of the judiciary department in particular, it might be inexpedient to insist rigorously on the principle of independence of departments; first, because peculiar qualifications being essential in the members, the primary consideration ought to be to select that mode of choice which best secures these qualifications; secondly, because the permanent tenure by which the appointments are held in that department, must soon destroy all sense of dependence on the authority conferring them." ${ }_{12}$

The President's compensation could not be increased or diminished, or the judges' compensation be diminished, while they were in office.

${ }^{708} 2$ id. 64-69.

${ }^{109} 2$ id. $522-523,530$.
${ }^{\text {so }} 2$ id. 538 .

${ }^{\mathrm{nI}} 2 i d .536-53^{8}$.
In Federalist, no. 5 I. 
The provisions apportioning the three powers to the three departments were doubtless intended, as they have been construed, to set limits to departures from the principle of the separation of powers. There was also a prohibition against public officers serving in Congress. ${ }^{113}$

On the other hand, there were a number of provisions for blending. Congress might provide by law for succession to the Presidency, in certain cases of vacancy. Congress might create inferior judicial tribunals. It might rule the District of Columbia. The House impeached, and the Senate tried impeachments. The Senate shared with the President the power to make appointments. The President shared with the Senate the power to make treaties. The President might, on extraordinary occasions, convene either House or both Houses, and in cases of disagreement between the Houses, "with respect to the time of adjournment," he might adjourn Congress. He was charged with the duty of informing Congress "of the state of the Union," and recommending "necessary and ... expedient" measures. The Vice President was president of the Senate. The President had a qualified veto. He had the power of granting reprieves and pardons, a familiar, if somewhat anomalous power, which Wilson in his lectures had no difficulty in pronouncing strictly executive. Finally, there was a striking provision for blending, ". . . the Congress may by law vest the appointment of such inferior officers as they think proper, in the President alone, in the courts of law, or in the heads of departments."

Notwithstanding the absence of perfect symmetry, the Constitution thus embodied the principle of a three-fold separation of powers. It was signed on September I7, I787. It was submitted by Congress to the people in state conventions; ratified by the necessary nine states by June 21 , I 788 ; and on the $13^{\text {th }}$ of September, I788, provision was made by Congress for putting the Constitution into operation. In the meantime all the states except North Carolina and Rhode Island had ratified the Constitution. Washington was inaugurated April 30, I789. North Carolina ratified January II, I790; and Rhode Island, June I6, I790.

It may be worth while to note briefly some of the references to the principle of the separation of powers made in the course of the debates in four of the state conventions. The conventions are selected because of their importance, and will be discussed, not in chronological order, but in an order determined by the relation of the speakers and their ideas, to the persons and ideas already discussed.

In Virginia, the tenth state to ratify the Constitution, there was, as in other states, vigorous opposition to ratification. This opposition con-

${ }^{\mathrm{rr}} \mathrm{Cf}$. as to the relation between departments, and control of emoluments, I Farrand, supra note $66,39 \mathrm{r}-394 ; 2 i d .44$. 
cerned itself, of course, with many other matters besides the separation of powers. But some of the objections to the proposed Constitution were founded on the view that it did not provide for a proper separation of powers.

Patrick Henry, a leader of the opposition, under whose summer's eloquence some members of the convention must at times have been restless, expressed various objections to the allotment of powers to the departments, not always making it clear whether he objected on grounds of the principle of the separation of powers, or on states' rights grounds. His most interesting argument was a challenge to Madison's theory that the separation of powers would be maintained in the federal government, because each department had the power and the incentive to resist encroachments by the other. Henry asked, "Where is the incentive?"

"Tell me not of checks on paper; but tell me of checks founded on self-love. . . .

"... In the British government there are real balances and checks: in this system there are only ideal balances. . . The President and senators have nothing to lose. They have not that interest in the preservation of the government that the king and lords have in England. They will, therefore, be regardless of the interests of the people...."

The reference to the Senate and the President gives the key to the Virginia opposition arguments connected with the separation of powers. Whether for sound reasons, or because of prejudices going back to colonial days, or the exigencies of debate, a number of influential members of the convention urged the danger of a Senate and President combination. Patrick Henry, ${ }^{\mathbf{x} 5}$ Monroe, ${ }^{\mathrm{xx} 6}$ Mason, ${ }^{\mathbf{x r} 7}$ Grayson, ${ }^{\mathrm{II} 8}$ all urged the danger that the Senate would become in effect an executive council, and the result would be executive tyranny.

Thus, Mason said:

"It has been wittily observed that the Constitution has married the President and Senate-has made them man and wife. I believe the consequence that generally results from marriage will happen here. They will be continually supporting and aiding each other: they will always consider their interest as united. We know the advantage the few have over the many. . . . The executive and legislative powers, thus connected, will destroy all balances: . . . . The President is tried by his counsellors."

${ }^{144} 3$ Elliot's Debates (I863), I64-I66. On the Virginia convention, see I Beveridge, Life of Marshall (IgIg), c. IX-XUr.

${ }^{115} 3$ Elliot's supra note Ix4, I64-I66, 512. Cf. 3 id., I72, 353-355 (danger of treaty giving up navigation rights on the Mississippi), $388,396,4 \mathrm{IO}$, for related criticisms.

${ }^{116} 3$ id. 22I-222, 48 g. Cf. 3 id. 218-219. ${ }^{177} 3$ id. 493-494.

${ }^{218} 3$ id. 49r. Cf. 3 id., 280, 563-564, 6I4. And $c f$. Dawson's criticism, 3 id. 608; and Tyler's, 3 id. 64r.

Ix9 Supra note II7. 
Mason also urged that the President's influence made continued reelection and consequent tyranny likely. ${ }^{\mathrm{x} 20} \mathrm{He}$ objected to the President's great power as commander in chief. ${ }^{\mathrm{I2I}} \mathrm{He}$ objected to the Vice President in the Senate. ${ }^{x 22}$ And he argued that the President's pardoning power gave him a dangerous capacity for corruption.

"... Now, I conceive that the President ought not to have the power of pardoning, because he may frequently pardon crimes which were advised by himself. It may happen, at some future day, that he will establish a monarchy, and destroy the republic. If he has the power of granting pardons before indictment, or conviction, may he not stop inquiry and prevent detection?" ${ }^{23}$

Madison, in answer, said:

"... it would be extremely improper to vest it [the power to pardon] in the House of Representatives, and not much less so to place it in the Senate; because numerous bodies were actuated more or less by passion, and might, in the moment of vengeance, forget humanity. It was an established practice in Massachusetts for the legislature to determine in such cases. It was found ... that two different sessions, before each of which the question came with respect to pardoning the delinquents of the rebellion, were governed precisely by different sentiments: the one would execute with universal vengeance, and the other would extend general mercy." 224

And Madison, ${ }^{\text {225 }}$ with his associates, Randolph, ${ }^{\mathrm{x} 26}$ John Marshall, ${ }^{\mathrm{x} 27}$ Corbin, ${ }^{x 28}$ Johnson, ${ }^{129}$ Lee, ${ }^{130}$ Nicholas, ${ }^{{ }^{31}}$ Pendleton, ${ }^{{ }^{132}}$ Stephen, ${ }^{{ }^{133}}$ defended the separation of powers provided for by the Constitution, with emphasis on the necessity for a checked legislature, and a strong executive.

Randolph, while he refused to sign the Constitution, ended by defending it. He said:

"Be so good as to recollect how we fared under the Confederation. ... Was it not a political farce to pretend to vest powers, without accompanying them with the means of putting them in execution? This want of energy was not a greater solecism than the blending together, and vesting in one body, all the branches of government. The utter inefficacy of this system was discovered, the moment the danger was over, by the introduction of peace; the accumulated public misfortunes that resulted from its inefficacy rendered an alteration necessary: this necessity was obvious to all America: attempts have accordingly been made for this purpose." ${ }_{334}$

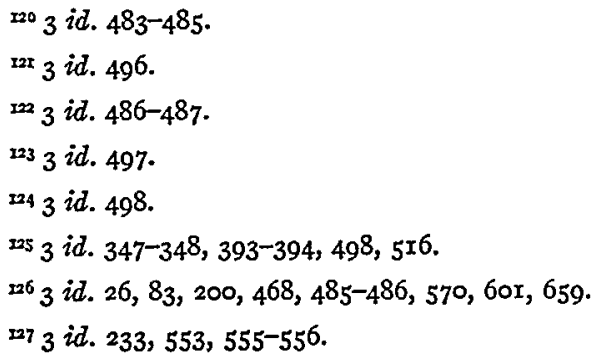

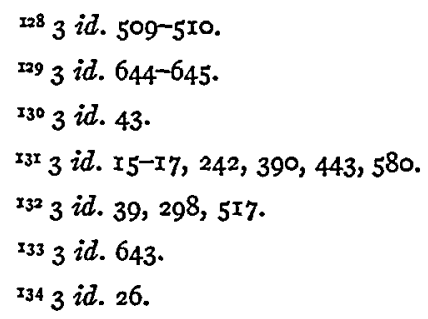


Again, Randolph said:

"But the amendability of the Confederation seems to have great weight on the minds of some gentlemen. To what point will the amendments go? What part makes the most important figure? What part deserves to be retained? In it one body has the legislative, executive, and judicial powers: but the want of efficient powers has prevented the dangers naturally consequent on the union of these. Is their union consistent with an augmentation of their power? Will you, then, amend it by taking away one of these three powers? Suppose, for instance, you only vested it with the legislative and executive powers, without any control on the judiciary; what must be the result? Are we not taught by reason, experience, and governmental history, that tyranny is the natural and certain consequence of uniting these two powers, or the legislative and judicial powers, exclusively, in the same body? If anyone denies it, I shall pass by him as an infidel not to be reclaimed. Whenever any two of these three powers are vested in one single body, they must, at one time or other, terminate in the destruction of liberty." ${ }_{135}$

No one in the convention specifically answered Patrick Henry's challenge to Madison's theory of the interaction of interested departments. All who referred to the question, however-Patrick Henry, ${ }^{, 36}$ Mason, $^{137}$ Grayson, ${ }^{{ }^{138}}$ Randolph, ${ }^{139}$ John Marshall, ${ }^{x 40}$ Nicholas $^{14 x}$-recognized and approved the doctrine of judicial review.

In Virginia, we have observed two different views of how the powers of government ought to be divided. It may be that Madison's advocacy of a strong executive, in the Federalist and the federal convention, helped determine the form which the issue took. A relatively "popular" view was that the popular branch of the legislature should be stronger, and the aristocratic branch and the executive weaker, than the Constitution had made them. A relatively conservative view, which finally prevailed, was that a legislature ought to be carefully checked, and an executive carefully strengthened, in a democratic state. Proponents of both views believed in a tripartite separation of powers.

From the Pennsylvania convention, only Wilson's speeches, and one of M'Kean's, are reported by Elliot. These speeches indicate that some of the objections made to the Constitution's separation of powers were rather doctrinaire, and of the sort which assume all blending to be irregular. A closely related and more substantial objection to the Senate's extensive powers was evidently strongly urged by the opposition.

M'Kean answered with a straight-forward defense of blending. ${ }^{\mathrm{I} 42}$

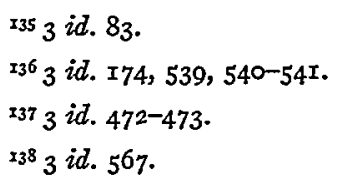

${ }^{139} 3$ id. 468.

${ }^{140} 3$ id. $553, C f .555^{-556}$.

${ }^{14} 3$ id. 443.

${ }^{x_{4} 2} 2$ id. $530,53 \mathrm{I}, 534-535,538,539$. 
Wilson displayed the characteristic approach and ideas, with which we are already familiar. He spoke of three powers, belonging each to one of three departments. ${ }^{143} \mathrm{He}$ spoke of the maintenance of each department's independence. ${ }^{\mathrm{I} 44} \mathrm{He}$ either minimized blending, ${ }^{\mathrm{I45}}$ or, in the case of the Senate, admitted its existence and his objection to it..$^{4^{6}} \mathrm{He}$ thought each department must and would resist encroachments. ${ }^{147} \mathrm{He}$ spoke, as of a familiar and accepted idea, of judicial review. ${ }^{\mathbf{4} 8}$ He urged the familiar practical reasons for a separation of powers. ${ }^{149}$

There was an interesting argument to the effect that while treaties are in one aspect legislation, they are a peculiar kind of legislation; which requires the sort of negotiation and secrecy that only the Senate and President can assure. ${ }^{\text {x50 }}$ There was a refined argument that the President's veto power is not legislative. ${ }^{\mathrm{x} 5 \mathrm{x}}$

"The effect of this power, upon this subject, is merely this: if he disapproves a bill, two thirds of the legislature become necessary to pass it into a law, instead of a bare majority. And when two thirds are in favor of the bill, it becomes a law, not by his, but by authority of the two houses of the legislature."

Wilson expressed surprise that the opposition objected rather to the Senate's powers than to the President's. He indicated he had expected opposition on the latter score. ${ }^{152}$ And he pointed out that objections to the Senate's powers came with bad grace from advocates of amendments to the existing Articles of Confederation, which concentrated all the power the central government had, in Congress. ${ }^{\text {.53 }}$

Again, proponents and opponents of the Constitution agreed in respecting the dogma of a separation of powers. But in Pennsylvania, so far as an issue was made of the form in which the dogma appeared in the Constitution, it was between those who believed that the framers of the Constitution had gone too far in giving powers to one branch of the legislature, and the advocates of the framers' scheme.

In the New York convention similar objections were made, and similarly answered.

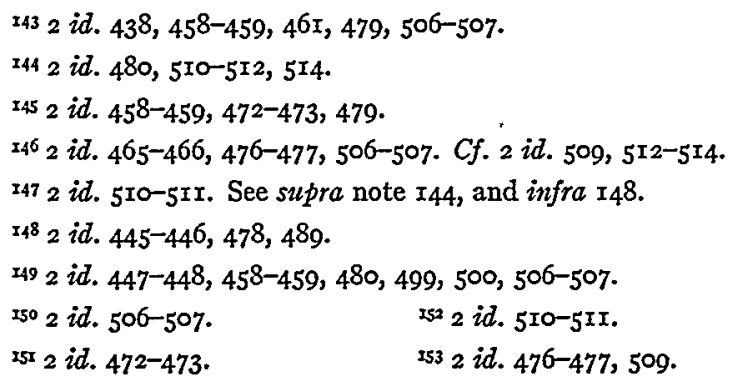


"Mr. G. [Gilbert] Livingston . . . , in the first place, considered the importance of the Senate as a branch of the legislature, in three points of view:-

"First, they would possess legislative powers coextensive with those of the House of Representatives except with respect to originating revenue laws; which, however, they would have power to reject or amend, as in the case of other bills. Secondly, they would have an importance, even exceeding that of the representative house, as they would be composed of a smaller number, and possess more firmness and system. Thirdly, their consequence and dignity would still further transcend those of the other branch, from their longer continuance in office. These powers, Mr. Livingston contended, rendered the Senate a dangerous body.

"He went on, in the second place, to enumerate and animadvert on the powers with which they were clothed in their judicial capacity, and in their capacity of council to the President, and in the forming of treaties. In the last place, as if too much power could not be given to this body, they were made, he said, a council of appointment, by whom ambassadors and other officers of state were to be appointed."

\section{Chancellor Robert Livingston answered:}

"One gentleman had enumerated the formidable powers of the Senate. . . . He had mentioned the power to try impeachments. But the power of impeaching was in the House of Representatives, and that was the important power. It could hardly be supposed that the representatives would exercise this power for the purposes of tyranny; but if they should, it certainly could be of no disadvantage to enable the Senate to check them. In the next place, he said, the power of appointing officers was mentioned. This was unfairly stated; the Senate had but a negative upon the President; they had only an advisory power. In making laws they had only a partial agency; they were checked by the representatives and President. To any unprejudiced examiner, he said, it would appear that the Constitution had provided every reasonable check, and that the authority of the Senate was sufficiently circumscribed. But the gentlemen would multiply checks till the new government was as relaxed and nerveless as the old one."

Again, both sides of the convention agreed on the paramount necessity of checks on the people's various representatives in government. And in New York, again, the opposition urged the necessity of additional safeguards against tyranny by the upper branch of the legislature. The only disagreement was over the distribution of checks. ${ }^{\mathrm{x} 6}$

Indeed one who, reading the debates in various conventions, sees this disagreement in some perspective, must often feel that the objections to the constitutional distribution of powers were rather minor weapons in the armory of opponents to the Constitution. At the same time, they seem to illustrate the point of view of the "popular opposition." The objections were always to the powers of the aristocratic Senate or the kingly President.

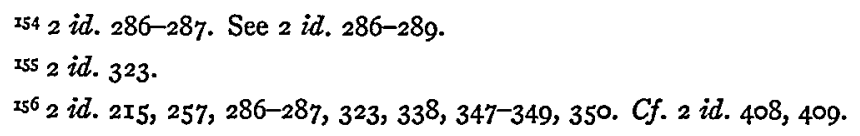


We have observed the views of Jefferson, Adams, Madison, and Wilson on the separation of powers. In the New York convention, a fifth Father of equal magnitude, expressed his opinion about the doctrine. Hamilton said:

"After all, sir, we must submit to this idea, that the true principle of a republic is, that the people should choose whom they please to govern them. Representation is imperfect in proportion as the current of popular favor is checked. This great source of free government, popular election, should be perfectly pure, and the most unbounded liberty allowed. Where this principle is adhered to; where, in the organization of the government, the legislative, executive, and judicial branches are rendered distinct; where, again, the legislature is divided into separate houses, and the operations of each are controlled by various checks and balances, and, above all, by the vigilance and weight of the state governments, - to talk of tyranny, and the subversion of our liberties, is to speak the language of enthusiasm."157

Again he said:

"After all our doubts, our suspicions, and speculations, on the subject of government, we must return at last to this important truth-that, when we have formed a constitution upon free principles, when we have given a proper balance to the different branches of administration, and fixed representation upon pure and equal principles, we may, with safety, furnish it with all the powers necessary to answer, in the most ample manner, the purposes of government. The great desiderata are, free representation and mutual checks. When these are obtained, all our apprehensions of the extent of power are unjust and imaginary. What, then, is the structure of this government? One branch of the legislature is to be elected by the people-by the same people who choose your state representatives. Its members are to hold their offices two years, and then return to their constituents. Here, sir, the people govern; here they act by their immediate representatives. You have also a Senate, constituted by your state legislatures, by men in whom you place the highest confidence, and forming another representative branch. Then, again, you have an executive magistrate, created by a form of election which merits universal admiration. In the form of this government, and in the mode of legislation, you find all the checks which the greatest politicians and the best writers have ever conceived. What more can reasonable men desire? Is there any one branch in which the whole legislative and executive powers are lodged? No. The legislative authority is lodged in three distinct branches, properly balanced; the executive is divided between two branches; and the judicial is still reserved for an independent body, who hold their office during good behavior. This organization is so complex, so skilfully contrived, that it is next to impossible that an impolitic or wicked measure should pass the scrutiny with success. Now, what do gentlemen mean by coming forward and declaiming against this government? Why do they say we ought to limit its power, to disable it, and to destroy its capacity of blessing the people? Has philosophy suggested, has experience taught, that such a government ought not to be trusted with every thing necessary for the good of society? Sir, when you have divided and nicely balanced the departments of government; when you have strongly connected the virtue of your rulers with their interest; when, in short, you have rendered your

2572 id. 257. 
system as perfect as human forms can be-you must place confidence; you must give power." ${ }_{558}$

"The true principle of government is this-make the system complete in its structure, give a perfect proportion and balance to its parts, and the powers you give it will never affect your security." 159

In Massachusetts, as in other states, opponents of the Constitution criticized blending, particularly in the Senate, and expressed fears of senatorial tyranny.

The Reverend Mr. Thacher, ${ }^{160}$ James Bowdoin, ${ }^{16 x}$ and Theophilus Parsons ${ }^{\mathrm{T} 2}$ ably defended the Constitution against these criticisms. They all frankly recognized the existence of blending. They urged, however, that departments differently chosen and with fundamental differences of function should adequately check each other. Thacher contrasted the American scheme of checks with the British royal tyranny. Bowdoin argued that state constitutions furnished precedents for such blending as there was, in the federal government. Parsons criticized the Articles of Confederation for uniting the "whole power, executive and legislative-in one body." Thacher thought an independent judiciary an important safeguard to life, liberty, and property.

Finally, Colonel Varnum ". . called on any gentleman to produce an instance where any government, consisting of three branches, elected by the people, and having checks on each other, as this has, abused the power delegated to them."163

\section{$\mathrm{V}$}

We have seen, in the first place, clear traces of the forces which produced our principle, and led to its application. Solicitude for liberty and property, and not unreasonable fear of what unchecked majority rule might do to them, seem the forces which did most to embody the principle in our constitutions. A complementary sense of the necessity for a strong and efficient executive contributed also to the same result.

We have seen, in the second place, the various forms which, in painfully emerging from chaos, the principle has taken. There are two functions of government, the legislative and executive; or three, the legislative, executive, and federative; or three others, the legislative, executive, and judicial. There are two departments of government, the legislative and executive;

${ }^{158} 2 i d .347-348$. And see $2 i d .348-350$.

1592 id. 350 .

${ }^{260} 2$ id. 145 .

${ }^{16 \mathrm{I}} 2$ id. 84,85 , I26-I 28 . 
or three, the lower legislative house, the upper legislative house, and the executive; or three others, the legislative, executive, and judicial; or four, by a combination of the two last classifications. Various views obtain about the importance of strengthening one department or another: in the period when our constitutions were forming, it was the prevailing view that legislatures were dangerous, and ought not to be too strong, while executives and judges would be likely to protect endangered interests, and ought to be strong. Though it was also derived from other premises, the doctrine of judicial review was a not unnatural corollary of this view.

The broad outlines of the principle emerged before some of its implications became clear. It was some time before the Fathers had a realization that to make the principle effective they ought, strictly, to provide for the separate choice and independent tenure of the important departments. At the same time they made the qualifying observations that they wanted an appointed judiciary, and that provision for impeachment was necessary. Madison's theory that the interaction of interested independent departments would preserve the system created by the Fathers, though it was challenged by Patrick Henry, seems to have influenced the development of the Constitution. The vitality of the principle of a separation of powers has been aided by the vitality of the related doctrine of judicial review.

The problem of blending is still a difficult one. Public opinion, legislatures, officials, and courts still fluctuate between Madison's relatively flexible view and Wilson's relatively strict position. Is it enough to prevent one department from exercising or limiting powers quite clearly given to another? Or do clear thinking and safety require that, except so far as constitutions expressly provide otherwise, no department shall exercise any powers except those which are in some analytical sense quite like its familiar and obviously appropriate powers?

In so far as workers and owners, the many and the few, have voluntarily co-operated these past years in improving industrial governments, their work seems in the old tradition of American government; and any further development is likely to show the influence of that tradition. In so far as Congress has given discretion to the President in the execution of policies, its action has raised a question about the application of the principle of the separation of powers. ${ }^{164}$

${ }^{36} 6_{4}$ See Black, The National Industrial Recovery Act and the Delegation of Legislative Power to the President, I9 Corn. L. Q. 389 (I934); Corwin, Some Probable Repercussions of "NIRA" on our Constitutional System, I72 Ann. Am. Academy I39, I42-I43 (r934). 
A limit on the many in the interests of the few was the first purpose of the principle as it appeared in American constitutions. Congress cannot of course give up its final control of policy, subject to judicial review, under our Constitution. ${ }^{165}$ The functions of government cannot, however, be simply or perfectly classified and apportioned to different organs of government. Blending has from the first been to some extent approved and relied on, in securing an effective balance in government. If practical needs require the exercise of a function whose nature is doubtful by the President, Congress will of course be given latitude in entrusting that function to the President, and the President in exercising it. The working balance in government is always given considerable protection by the separate choice and independent tenure of the different branches of government. Is it not consistent with the main features of classical doctrine, for Congress to entrust large powers to the strong executive created by the Constitution, in dealing with unique domestic and international events?

${ }^{265}$ Panama Refining Co. v. Ryan, 55 Sup. Ct. 24 I (I935). See 48 Harr. L. Rev. 798 (I935) 